\title{
,an \\ Optimal Selection of Empirical Reference Evapotranspiration Method in 36 Different Agricultural Zones of China
}

\author{
Yong Yang ${ }^{1}$, Rensheng Chen ${ }^{1,2, *}$, Chuntan Han ${ }^{1}$, Zhangwen Liu ${ }^{1}$ and Xiqiang Wang ${ }^{1}$ \\ 1 Qilian Alpine Ecology and Hydrology Research Station, Northwest Institute of Eco-Environment and \\ Resources, Chinese Academy of Sciences, Lanzhou 730000, China; yy177@lzb.ac.cn (Y.Y.); \\ hancht@lzb.ac.cn (C.H.); zwliu@lzb.ac.cn (Z.L.); wangxq@lzb.ac.cn (X.W.) \\ 2 College of Urban and Environmental Sciences, Northwestern University, Xi'an 710127, China \\ * Correspondence: crs2008@lzb.ac.cn
}

check for

updates

Citation: Yang, Y.; Chen, R.; Han, C.; Liu, Z.; Wang, X. Optimal Selection of Empirical Reference Evapotranspiration Method in 36 Different Agricultura Zones of China. Agronomy 2022, 12, 31. https://doi.org/10.3390/ agronomy12010031

Academic Editor: Alberto San Bautista

Received: 5 November 2021

Accepted: 22 December 2021

Published: 24 December 2021

Publisher's Note: MDPI stays neutral with regard to jurisdictional claims in published maps and institutional affiliations.

Copyright: (C) 2021 by the authors. Licensee MDPI, Basel, Switzerland. This article is an open access article distributed under the terms and conditions of the Creative Commons Attribution (CC BY) license (https:// creativecommons.org/licenses/by/ $4.0 /)$.

\begin{abstract}
The Food and Agriculture Organization has proposed the current version of the PenmanMonteith method (FAO56-PM) as the standard for calculating reference evapotranspiration $\left(\mathrm{ET}_{0}\right)$; however, high meteorological data requirements limit its application in many areas. There is thus an urgent need to identify the best alternative empirical method to accurately calculate $\mathrm{ET}_{0}$ in regions that lack sufficient meteorological data. In this study, three temperature-based methods and five radiation-based methods were evaluated using $\mathrm{ET}_{0}$ values generated using the FAO56-PM method in 36 agricultural zones in China based on meteorological data from 823 stations, measured between 2011 and 2020. The results showed that the optimal temperature-based method and radiation-based method differed for different agricultural zones, and no one temperature method or radiation method could be suitable for all agricultural zones. The eight empirical methods were regionally calibrated to improve the $\mathrm{ET}_{0}$ calculation accuracy in the different zones. The relationship between the optimal methods and climatic conditions showed that the most reliable empirical method could be selected according to the local annual mean temperature and aridity index. The results provide useful guidance for the selection of reliable empirical $\mathrm{ET}_{0}$ methods in agricultural zones outside China.
\end{abstract}

Keywords: reference evapotranspiration; empirical methods; climatic conditions; agricultural zones; spatial differences

\section{Introduction}

Evapotranspiration (ET) is one of the most important components of the hydrological cycle, directing approximately $60 \%$ of the precipitated water on land back to the atmosphere [1]. Accurate estimations of actual evapotranspiration (ET $\mathrm{E}_{\mathrm{a}}$ ) are highly significant for many fields, such as agronomy, hydrology, climatology, meteorology, ecology, and environmental science [2]. However, direct observations of $\mathrm{ET}_{\mathrm{a}}$ remain unavailable in many locations worldwide [3,4], and several methods have been proposed to estimate $\mathrm{ET}_{\mathrm{a}}$ in these areas [5]. For example, the product of the reference crop evapotranspiration $\left(\mathrm{ET}_{0}\right)$ and crop coefficient is a widely used method worldwide for estimating $\mathrm{ET}_{\mathrm{a}}$ [3,6-8], and it has been recommended by the Food and Agriculture Organization (FAO) [9] for computing crop water requirements. Accurate $\mathrm{ET}_{0}$ calculation is a prerequisite for obtaining $\mathrm{ET}_{\mathrm{a}}$ and is the fundamental basis for irrigation water requirements and optimizing irrigation schedules, crop quality, and productivity $[2,10]$. $\mathrm{ET}_{0}$ also represents ET from a hypothetical reference surface and has been used to express the evaporative demand of the atmosphere [11]. The temporal and spatial variations of $\mathrm{ET}_{0}$ have also attracted extensive research attention with regard to climate change $[12,13]$.

The $\mathrm{ET}_{0}$ term was first proposed by the FAO to represent evapotranspiration from a defined vegetated surface [14]. Several methods have since been developed to calculate $\mathrm{ET}_{0}$ and can be generally classified into three categories: (1) temperature-based methods, (2) radiation-based methods, and (3) combination methods [5,15]. The FAO paper No. 24 
by Doorenbos and Pruitt (1977) recommended several methods for calculating $\mathrm{ET}_{0}$ that provided users with the freedom to match the data to a given method. However, many users expressed dissatisfaction with the $\mathrm{ET}_{0}$ selection and the differences between the results obtained using different methods [16]. The FAO paper No. 56 by Allen et al. [9] defined the reference surface as a hypothetical grass reference crop with an assumed crop height of $0.12 \mathrm{~m}$, fixed surface resistance of $70 \mathrm{~s} \cdot \mathrm{m}^{-1}$, and albedo of 0.23 , and recommended the sole use of the Penman-Monteith (FAO56-PM) method to calculate $\mathrm{ET}_{0}$. The FAO56-PM approach has hence become the standard method for calculating $\mathrm{ET}_{0}$ in different climate regions worldwide [2,15].

However, the FAO56-PM method requires a large number of weather variables (e.g., air temperature, relative humidity, wind speed, solar radiation) that are not measured in many meteorological stations, especially in developing areas $[15,17]$. Most studies have concluded that the $\mathrm{ET}_{0}$ values obtained using combined methods are more consistent with the FAO56-PM method than those from temperature-based or radiation-based methods [18-20]. However, this does not solve the problem of how to select a reliable method in data-deficient regions, because the meteorological data requirements of the combined methods are similar to those of the FAO56-PM method. The application of the FAO56-PM method and the combined methods to calculate $\mathrm{ET}_{0}$ is therefore limited in many regions due to insufficient meteorological data, and other simpler empirical methods based on temperature or radiation are still widely used [21-23]. Several studies have evaluated the performance of these $\mathrm{ET}_{0}$ methods under different climate conditions to verify their accuracy and assist in the process by which the optimal empirical method is selected. The performances of empirical $\mathrm{ET}_{0}$ methods based on radiation or temperature have been shown to vary in different climate zones. For example, Valle Júnior et al. [24] reported that the De Bruin-Keijman method and Priestley-Taylor method were better for calculating $\mathrm{ET}_{0}$ in a Brazilian savannah than other radiation-based methods, whereas Pandey et al. [25] reported that the Irmak method and Turc method were the two best radiation-based methods for the northeastern region of India. Tabari et al. [26] found that the Blaney-Criddle method performed better than other temperature-based methods in humid areas of Iran, whereas Bourletsikas et al. [20] reported that the Hargreaves method was the best temperature-based method for grass-covered areas in a Mediterranean forest in Greece. As many $\mathrm{ET}_{0}$ methods have been developed for specific hydroclimatic conditions, it is highly recommended to evaluate and calibrate these methods when used in climate zones beyond their calibration zones $[27,28]$. Furthermore, the concept of $\mathrm{ET}_{0}$ was mainly developed on the basis of the concept of potential evapotranspiration (PET) [2,5]. In the review paper by McMahon et al. (2016), PET is defined as 'the upper limit of evaporation under constant meteorological and surface temperature conditions from a surface (vegetation, bare soil, or open water) that is saturated and of such extent to negate effects of local advection', and $\mathrm{ET}_{0}$ represents evapotranspiration from a defined vegetated surface [5]. This has led to confusion regarding the use of the two concepts and thus resulted in the simultaneous evaluation of PET methods together with $\mathrm{ET}_{0}$ methods. For example, several studies have evaluated the Penman, Priestley-Taylor, and Turc methods in the context of calculating $\mathrm{ET}_{0}[20,24,29,30]$; however, such methods should be used to calculate PET rather than $\mathrm{ET}_{0}[2,5,31]$.

The weather and climate vary substantially across China, owing to the country's vast size. In recent years, several studies in China have evaluated different $\mathrm{ET}_{0}$ methods at specific experimental sites [19,32-34] and specific climate regions in China [35-37]. On a national scale, Peng et al. [38] evaluated $10 \mathrm{ET}_{0}$ methods in seven climate regions in China, and Yang et al. [39] evaluated six $\mathrm{ET}_{0}$ methods in four climate regions in China. Due to the country's vast climatic differences, the division of its area into four or seven climate zones is insufficient to distinguish its climate differences. Sensitivity analysis showed significant spatial differences within each of the four defined climatic zones in terms of the dominant meteorological factors that affect $\mathrm{ET}_{0}$ [40]. Song et al. [41] accordingly divided Northeast China, which is mostly characterized by a temperate monsoon climate, into 
eight sub-regions. The evaluation of $11 \mathrm{ET}_{0}$ methods showed that the optimal choice of empirical method significantly differed between the different sub-regions, even within the same climate zone. Furthermore, due to the confusion regarding the mutual use of PET and $\mathrm{ET}_{0}$, many PET methods have been used in the above-mentioned studies for comparative evaluation with $\mathrm{ET}_{0}$ methods in China. It is therefore necessary to evaluate the $\mathrm{ET}_{0}$ methods, while excluding PET methods, in more detailed area divisions in China to appropriately recommend the most suitable temperature-based/radiation-based methods for the different climate zones.

To systematically address these issues, the objectives of this study are as follows: (1) to evaluate eight empirical $\mathrm{ET}_{0}$ methods with values obtained using the FAO56-PM method in 36 different agricultural zones in China; (2) to recommend the most reliable empirical $\mathrm{ET}_{0}$ method in the different agricultural zones; and (3) to calibrate the $\mathrm{ET}_{0}$ methods in the agricultural climate zones.

\section{Materials and Methods}

\subsection{Study Area}

China can be divided into 10 zones on the basis of temperature, or 4 regions on the basis of aridity/humidity. The total area can be further divided into 38 agricultural zones (Figure 1). The boundaries of the 38 agricultural zones are provided by the Resource and Environment Science and Data Center (https: / / www.resdc.cn/, accessed on 26 November 2020). The two agricultural zones in Taiwan are not considered due to insufficient data availability; thus, 36 agricultural zones are discussed in this study. The code, location, annual mean precipitation, air temperature, $\mathrm{ET}_{0}$, and aridity index [42] (2011-2020) of the 38 total agricultural zones are listed in Table 1.

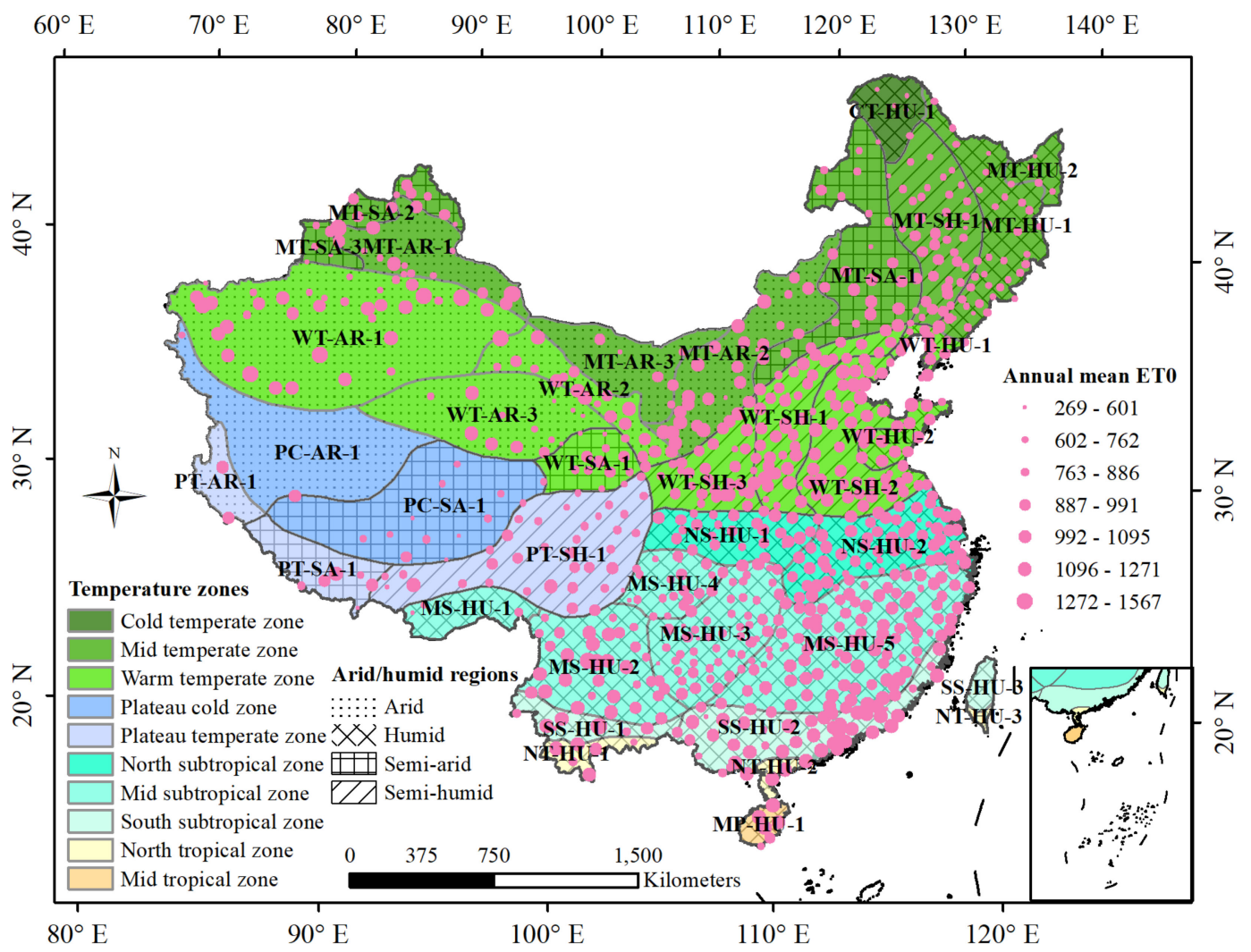

Figure 1. Spatial distribution of 38 agricultural zones in China and annual mean reference crop evapotranspiration $\left(\mathrm{ET}_{0}, \mathrm{~mm}\right)$ values calculated using the FAO56-PM method from 2011 to 2020 at 823 meteorological stations. 
Table 1. Agricultural zones in China and their meteorological conditions (2011-2020).

\begin{tabular}{|c|c|c|c|c|c|c|c|c|}
\hline Temperature Zone & $\begin{array}{l}\text { Arid/Humid } \\
\text { Region }\end{array}$ & Code & Location & NMS & $\begin{array}{c}T_{a} \\
\left({ }^{\circ} \mathrm{C}\right)\end{array}$ & $\begin{array}{c}P \\
(\mathrm{~mm})\end{array}$ & $\begin{array}{c}\mathrm{ET}_{0} \\
(\mathrm{~mm})\end{array}$ & $A I$ \\
\hline Cold temperate zone & Humid & CT-HU-1 & $\begin{array}{c}\text { Northern Greater Hinggan } \\
\text { Mountains }\end{array}$ & 5 & -1.8 & 521 & 568 & 0.77 \\
\hline Mid temperate zone & Humid & MT-HU-1 & $\begin{array}{c}\text { Lesser Hinggan } \\
\text { Mountains-Changbai Mountains }\end{array}$ & 36 & 4.9 & 694 & 741 & 0.79 \\
\hline Mid temperate zone & Humid & MT-HU-2 & Sanjiang Plain & 4 & 3.8 & 558 & 639 & 0.72 \\
\hline Mid temperate zone & Semi-humid & MT-SH-1 & Songliao Plain & 39 & 5.4 & 567 & 826 & 0.58 \\
\hline Mid temperate zone & Semi-arid & MT-SA-1 & Eastern Inner Mongolia & 26 & 4.2 & 385 & 890 & 0.37 \\
\hline Mid temperate zone & Semi-arid & MT-SA-2 & $\begin{array}{l}\text { Northwestern of } \\
\text { Northern Xinjiang }\end{array}$ & 9 & 5.4 & 209 & 865 & 0.21 \\
\hline Mid temperate zone & Semi-arid & MT-SA-3 & Western of Northern Xinjiang & 5 & 6.8 & 263 & 681 & 0.33 \\
\hline Mid temperate zone & Arid & MT-AR-1 & Northern Xinjiang & 15 & 7.1 & 178 & 959 & 0.16 \\
\hline Mid temperate zone & Arid & MT-AR-2 & Central Inner Mongolia & 26 & 7.2 & 242 & 1012 & 0.20 \\
\hline Mid temperate zone & Arid & MT-AR-3 & Western Inner Mongolia & 6 & 8.9 & 73 & 755 & 0.08 \\
\hline Warm temperate zone & Humid & WT-HU-1 & Liaodong Peninsula & 14 & 10.1 & 604 & 872 & 0.58 \\
\hline Warm temperate zone & Humid & WT-HU-2 & Shandong Peninsula & 13 & 13.2 & 701 & 1003 & 0.59 \\
\hline Warm temperate zone & Semi-humid & WT-SH-1 & North China Mountains & 41 & 10.4 & 518 & 973 & 0.45 \\
\hline Warm temperate zone & Semi-humid & WT-SH-2 & North China Plain & 50 & 14.3 & 667 & 986 & 0.58 \\
\hline Warm temperate zone & Semi-humid & WT-SH-3 & Loess Plateau & 34 & 10.8 & 568 & 925 & 0.52 \\
\hline Warm temperate zone & Semi-arid & WT-SA-1 & Qinghai & 11 & 4.9 & 432 & 810 & 0.45 \\
\hline Warm temperate zone & Arid & WT-AR-1 & Southern Xinjiang & 35 & 10.4 & 97 & 1026 & 0.08 \\
\hline Warm temperate zone & Arid & WT-AR-2 & Hexi Corridor & 21 & 8.3 & 171 & 1013 & 0.15 \\
\hline Warm temperate zone & Arid & WT-AR-3 & Qaidam Basin & 13 & 3.5 & 144 & 791 & 0.15 \\
\hline Plateau cold zone & Semi-arid & PC-SA-1 & Southern Qiangtang & 13 & 0.1 & 385 & 734 & 0.44 \\
\hline Plateau cold zone & Arid & PC-AR-1 & Northern Qiangtang & 1 & 5.1 & 71 & 743 & 0.08 \\
\hline Plateau temperate zone & Semi-humid & PT-SH-1 & Western Sichuan-Eastern Tibetan & 38 & 6.1 & 640 & 838 & 0.65 \\
\hline Plateau temperate zone & Semi-arid & PT-SA-1 & Southern flank of Himalayas & 6 & 4.9 & 352 & 899 & 0.33 \\
\hline Plateau temperate zone & Arid & PT-AR-1 & Western Tibetan & 2 & 3.1 & 118 & 1042 & 0.10 \\
\hline North subtropical zone & Humid & NS-HU-1 & Upper and middle Han River & 25 & 15.3 & 910 & 922 & 0.85 \\
\hline North subtropical zone & Humid & NS-HU-2 & $\begin{array}{l}\text { Middle and lower reaches of the } \\
\text { Yangtze River }\end{array}$ & 58 & 16.7 & 1278 & 951 & 1.15 \\
\hline Mid subtropical zone & Humid & MS-HU-1 & Southern Tibetan & 3 & 6.4 & 397 & 683 & 0.49 \\
\hline Mid subtropical zone & Humid & MS-HU-2 & Yunnan Plateau & 31 & 15.3 & 890 & 1026 & 0.75 \\
\hline Mid subtropical zone & Humid & MS-HU-3 & Guizhou Plateau & 50 & 16.3 & 1197 & 842 & 1.23 \\
\hline Mid subtropical zone & Humid & MS-HU-4 & Sichuan Basin & 22 & 17.3 & 1081 & 834 & 1.11 \\
\hline Mid subtropical zone & Humid & MS-HU-5 & Jiangnan hilly region & 103 & 18.6 & 1617 & 953 & 1.46 \\
\hline South subtropical zone & Humid & SS-HU-1 & Southern Yunnan Mountain & 8 & 19.5 & 930 & 1020 & 0.79 \\
\hline South subtropical zone & Humid & SS-HU-2 & $\begin{array}{l}\text { Fujian and Guangdong } \\
\text { hilly region }\end{array}$ & 46 & 22.1 & 1618 & 1049 & 1.34 \\
\hline South subtropical zone & Humid & SS-HU-3 & Northern Taiwan & 0 & - & - & - & - \\
\hline North tropical zone & Humid & NT-HU-1 & Southern Yunnan valley & 6 & 20.3 & 1409 & 1000 & 1.24 \\
\hline North tropical zone & Humid & NT-HU-2 & $\begin{array}{l}\text { Leizhou Peninsula and } \\
\text { Northern Hainan }\end{array}$ & 2 & 23.6 & 1622 & 1193 & 1.17 \\
\hline North tropical zone & Humid & NT-HU-3 & Southern Taiwan & 0 & - & - & - & - \\
\hline Mid tropical zone & Humid & MP-HU-1 & Southern Hainan & 6 & 24.4 & 1816 & 1085 & 1.45 \\
\hline
\end{tabular}

Note. NMS, number of meteorological stations; $P$, annual mean precipitation; $T_{a}$, annual mean air temperature $\mathrm{ET}_{0}$, annual reference evapotranspiration; $A I$, aridity index, the ratio of annual mean precipitation to the annual mean potential evapotranspiration calculated by the Penman method (see Supplementary Materials). 


\subsection{Data Collection}

Daily meteorological data collected from 823 stations were obtained from the China Meteorological Administration (http:/ / data.cma.cn/, accessed on 19 March 2021). The variables measured by the meteorological stations include air temperature $\left({ }^{\circ} \mathrm{C}\right)$, relative humidity (\%) at $2 \mathrm{~m}$ height, wind speed at $10 \mathrm{~m}$ height $\left(\mathrm{m} \cdot \mathrm{s}^{-1}\right)$, and sunshine duration (h). The wind speed at $2 \mathrm{~m}$ height, radiations, and other variables required for calculating $\mathrm{ET}_{0}$ by using various methods were estimated following the procedure described in the FAO paper No. 56 [9] (seen in the Supplementary Materials). Chinese meteorological stations began observations in the 1950s; however, in the early stages, the observation variables measured at certain meteorological stations were incomplete and there are thus numerous missing periods in the early data records. Although ET analysis ideally requires a 30-year timeline, evaluation of $\mathrm{ET}_{0}$ methods can be completed on a smaller timeline [17-21]. To include as many meteorological stations as possible, the research period in this study was restricted to 2011-2020. The daily $\mathrm{ET}_{0}$ values were calculated from the daily meteorological data and then processed into annual values.

\subsection{Selected $E T_{0}$ Methods}

A total of eight empirical $\mathrm{ET}_{0}$ methods were selected, comprising two categories: three temperature-based methods and five radiation-based methods. The three temperaturebased methods are the FAO24 Blaney-Criddle (FAO24-BC), Hargreaves-Samani (H-S), and Valiantzas temperature (V-T) methods. The five radiation-based methods are the FAO24 radiation (FAO24-R), Jensen-Haise (J-H), Jones-Ritchie (J-R), and Irmak and Valiantzas radiation (V-R) methods. The equations of the eight empirical $\mathrm{ET}_{0}$ methods and the FAO56PM method are briefly presented in Table 2, and detailed information can be found in the references listed therein.

Table 2. Reference evapotranspiration $\left(\mathrm{ET}_{0}\right)$ models selected for this study.

\begin{tabular}{|c|c|c|c|c|}
\hline Category & No. & Models & Equation & Reference \\
\hline \multirow[t]{3}{*}{ Temperature-based } & 1 & FAO-24 Blaney-Criddle (FAO24-BC) & $E T_{0}=a_{0}+b_{0} p\left(0.46 T_{a}+8.13\right)$ & [43] \\
\hline & 2 & Hargreaves-Samani (H-S) & $E T_{\mathrm{o}}=0.0023 R_{a}\left(T_{a}+17.8\right)\left(T_{\max }-T_{\min }\right)^{0.5} / \lambda$ & [44] \\
\hline & 3 & Valiantzas temperature (V-T) & $\begin{array}{l}E T_{\mathrm{o}} \approx 0.00668 R_{a}\left[\left(T_{\max }-T_{\text {dew }}\right)\left(T_{a}+9.5\right)\right]^{0.5}-0.0696\left(T_{\max }-T_{\text {dew }}\right) \\
-0.024\left(T_{a}+20\right)(1-R H / 100)-0.00455 R_{a}\left(T_{\max }-T_{\text {dew }}\right)^{0.5} \\
+0.0984\left(T_{a}+17\right)\left(1.03+0.00055 T_{d}^{2}-R H / 100\right)\end{array}$ & [45] \\
\hline \multirow[t]{5}{*}{ Radiation-based } & 4 & FAO24 radiation (FAO24-R) & $E T_{\mathrm{o}}=b\left(\frac{\Delta}{\Delta+\gamma} R_{s}\right) / \lambda-0.3$ & [43] \\
\hline & 5 & Jensen-Haise (J-H) & $\begin{array}{c}E T_{0}=\frac{C_{T}\left(T_{a}-T_{x}\right) R_{S}}{\lambda} \\
C_{T}=1 /\left[(38-(2 H / 305))+7.3 \times 5 /\left(e_{2}-e_{1}\right)\right] \\
T_{x}=-2.5-1.4\left(e_{2}-e_{1}\right)-H / 550\end{array}$ & [31] \\
\hline & 6 & Jones-Ritchie (J-R) & $\begin{aligned} & E T_{0}=\alpha_{1}\left[3.87 \times 10^{-3} \cdot R_{s}\left(0.6 T_{\max }+0.4 T_{\min }+29\right)\right] \\
& \alpha_{1}= \begin{cases}1.1 & 5<T_{\max }<35 \\
1.1+0.05\left(T_{\max }-35\right) & T_{\max }>35 \\
0.01 \exp \left[0.18\left(T_{\max }+20\right)\right] & T_{\max }<5\end{cases} \end{aligned}$ & [26] \\
\hline & 7 & Irmak & $E T_{\mathrm{o}}=-0.611+0.149 R_{s}+0.079 T_{a}$ & [46] \\
\hline & 8 & Valiantzas radiation (V-R) & $\begin{array}{l}E T_{\mathrm{o}} \approx 0.0393 R_{s}\left(T_{a}+9.5\right)^{0.5}-0.19 R_{s}^{0.6} \varphi^{0.15} \\
+0.0061\left(T_{a}+20\right)\left(1.12 T_{a}-T_{\min }-2\right)^{0.7}\end{array}$ & [47] \\
\hline Standard & 9 & FAO56 Penman-Monteith (FAO56-PM) & $E T_{0}=\frac{0.408 \Delta\left(R_{n}-G\right)+\gamma u_{2} \frac{900}{T_{a}+273}\left(e_{s}-e_{a}\right)}{\Delta+\gamma\left(1+0.34 u_{2}\right)}$ & [9] \\
\hline
\end{tabular}

Note. $\mathrm{ET}_{0}$, reference evapotranspiration $\left(\mathrm{mm} \cdot \mathrm{day}^{-1}\right) ; T_{a}$ average daily air temperature $\left({ }^{\circ} \mathrm{C}\right) ; T_{\max }$ maximum temperature $\left({ }^{\circ} \mathrm{C}\right) ; T_{\min }$ minimum temperature $\left({ }^{\circ} \mathrm{C}\right) ; T_{d}=T_{\max }-T_{\min } ; u_{2}$, wind speed at $2 \mathrm{~m}\left(\mathrm{~m} \cdot \mathrm{s}^{-1}\right) ; R H$ relative humidity (\%); $R H_{m i n}$, minimum relative humidity $(\%) ; H$, elevation $(\mathrm{m}) ; e_{s}$, saturation vapor pressure $(\mathrm{kPa}) ; e_{a}$, actual vapor pressure $(\mathrm{kPa}) ; e_{2}$, saturation vapor pressure $(\mathrm{kPa})$ at the maximum temperature; $e_{1}$, saturation vapor pressure $(\mathrm{kPa})$ at the minimum temperatures; $\Delta$, slope of the vapor pressure curve $\left(\mathrm{kPa} \cdot{ }^{\circ} \mathrm{C}^{-1}\right) ; R_{a}$, extraterrestrial radiation $\left(\mathrm{MJ} \cdot \mathrm{m}^{-2} \cdot \mathrm{day}^{-1}\right)$, which is a function of the station latitude and Julian day; $R_{s}$, incident solar radiation $\left(\mathrm{MJ} \cdot \mathrm{m}^{-2}\right.$. day $\left.{ }^{-1}\right) ; R_{n}$, net radiation $\left(\mathrm{MJ} \cdot \mathrm{m}^{-2}\right.$. day $\left.{ }^{-1}\right) ; G$, soil heat flux density $\left(\mathrm{MJ} \cdot \mathrm{m}^{-2}\right.$. day $\left.^{-1}\right)$, which can be neglected at a daily time step; $\lambda$, latent heat of vaporization $\left(\mathrm{MJ} \cdot \mathrm{kg}^{-1}\right) ; \gamma$, psychrometric constant $\left(\mathrm{kPa} \cdot{ }^{\circ} \mathrm{C}^{-1}\right) ; N$, hours of sunshine duration $(\mathrm{h}) ; p$, percentage of annual daylight hours for any day of the year; $p=N_{j} /\left(\sum_{i=1}^{365} N_{i}\right) \times 100 ; a_{0}=0.0043 R H_{\min }-n / N-1.41$; $b_{0}=0.82-0.0041 R H_{\min }+1.07 n / N+0.066 u_{2}-0.006 R H_{\min } \cdot n / N-0.0006 R H_{\min } \cdot u_{2} ;$ $b=1.066-0.13 \times 10^{-2} R H+0.045 u_{2}-0.20 \times 10^{-3} R H u_{2}-0.135 \times 10^{-4} R H^{2}-0.11 \times 10^{-2} u_{2}^{2}$. 


\subsection{Calibration Method}

Allen et al. [9] recommended using linear regression to calibrate the empirical $\mathrm{ET}_{0}$ methods using the $\mathrm{ET}_{0}$ values obtained by the FAO56-PM method, and this calibration method has been widely adopted worldwide [35,38,39,48-50]. The calibration process uses the following expression:

$$
E T_{F A O 56-P M}=a \cdot E T_{0}+b
$$

where $E T_{F A O 56-P M}$ is the $\mathrm{ET}_{0}$ value calculated by the FAO56-PM method, $\mathrm{ET}_{0}$ is the $\mathrm{ET}_{0}$ value calculated by one of the eight empirical $\mathrm{ET}_{0}$ methods, and $a$ and $b$ are the calibrated coefficients.

\subsection{Evaluation Criteria and Statistical Analysis}

Statistical indices were used to quantitatively analyze the $\mathrm{ET}_{0}$ modeling performance. The $\mathrm{ET}_{0}$ values calculated using the eight methods and standard $\mathrm{ET}_{0}$ values calculated using the FAO56-PM method were compared using a series of statistical criteria as follows:

$$
\begin{gathered}
R^{2}=\left[\operatorname{cov}\left(E T_{0}, E T_{F A O 56-P M}\right) / \sigma E T_{0} \sigma E T_{F A O 56-P M}\right]^{2} \\
M A E=\frac{1}{n} \sum_{i=1}^{n}\left|E T_{0, i}-E T_{F A O 56-P M, i}\right| \\
R M S E=\sqrt{\frac{\sum_{i=1}^{n}\left(E T_{0, i}-E T_{F A O 56-P M, i}\right)^{2}}{n}} \\
N S E=1-\frac{\sum_{i=1}^{n}\left(E T_{0, i}-E T_{F A O 56-P M, i}\right)^{2}}{\sum_{i=1}^{n}\left(E T_{F A O 56-P M, i}-\overline{E T_{F A O 56-P M, i}}\right)^{2}}
\end{gathered}
$$

where $R^{2}, M A E, R M S E$, and NSE are the coefficient of determination, mean absolute error $\left(\mathrm{mm} \cdot \mathrm{day}^{-1}\right)$, root mean square error $\left(\mathrm{mm} \cdot \mathrm{day}^{-1}\right)$, and Nash-Sutcliffe efficiency, respectively. $n$ is the number of statistical days, and $\operatorname{cov}$ and $\sigma$ are the covariance and standard deviation, respectively. $R^{2}$ values range from 0 to $1, M A E$ and $R M S E$ values range from 0 to $\infty$, and NSE values range from $-\infty$ to 1 . The perfect fit method is obtained when $N S E$ and $R^{2}$ are equal to 1 , and MAE and RMSE are equal to 0 .

Statistical analysis was conducted both for the overall time periods and for each individual month. The analysis was first carried out at each meteorological station, and the average statistical index values of all of the meteorological stations were taken as the statistical indices in the different agricultural zones.

To select the optimal temperature-based or radiation-based empirical $\mathrm{ET}_{0}$ method in each agricultural zone, referring to the method presented by Silva et al. [51], the following performance index was used to rank the performances of the empirical methods:

$$
P I=R^{2} \cdot N S E
$$

where $P I$ is the performance index of the empirical method. Higher PI values reflect better performance, and when $P I<0$, the method is not recommended for calculating the daily $\mathrm{ET}_{0}$.

The classical statistics of the mean $(\bar{X})$ and coefficient of variation $(C V)$ were obtained according to:

$$
\begin{gathered}
\bar{X}=\frac{1}{n} \sum_{i=1}^{n} X_{i} \\
s=\sqrt{\frac{1}{n-1} \sum_{i=1}^{n}\left(X_{i}-\bar{X}\right)^{2}} \\
C V=s / \bar{X}
\end{gathered}
$$




\section{Results}

\subsection{ET 0 Values Calculated Using the FAO56-PM and Empirical Methods}

The results obtained using the FAO56-PM method indicated that the area-averaged annual mean $\mathrm{ET}_{0}$ in China between 2011 and 2020 was approximately $893.0 \mathrm{~mm}$. The $\mathrm{ET}_{0}$ values calculated using the eight evaluated empirical methods showed large discrepancies with the FAO56-PM values, and the $C V$ of annual mean $\mathrm{ET}_{0}$ values calculated using the nine total methods was 0.14 . The maximum and minimum calculated annual mean $\mathrm{ET}_{0}$ values were obtained using the FAO24- $\mathrm{R}$ method and J-H method, respectively, yielding values of 1160.5 and $782.1 \mathrm{~mm}$ (Figure 2).

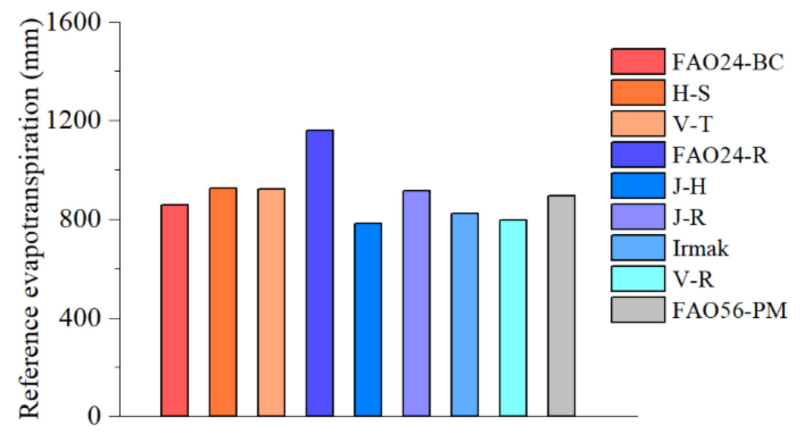

Figure 2. Annual mean reference evapotranspiration in China during the 2011-2020 period, calculated using nine different methods.

The zones with the highest $\mathrm{ET}_{0}$ values calculated using the FAO56-PM method were located on Hainan Island and its nearby areas (NT-HU-2 and MP-HU-1), whereas the lowest $\mathrm{ET}_{0}$ values were obtained from two zones in Northeast China (CT-HU-1 and MTHU-2) and one zone in Northern Xinjiang (MT-SA-3) (Figure 3a). The $C V$ values of the annual mean $\mathrm{ET}_{0}$ from the nine total methods exhibited spatial differences across the different agricultural zones (Figure $3 \mathrm{~b}$ ). South China was the region with the lowest $C V$, indicating minor variability of the annual mean $\mathrm{ET}_{0}$ values calculated using the different methods. The agricultural zones PC-SA- 1 and PT-AR- 1 in the Tibet Plateau and CT-HU-1 in Northeast China showed high $C V$ values, indicating substantial variations in the annual mean $\mathrm{ET}_{0}$ values calculated using the different methods. The above results indicate that there were differences among the $\mathrm{ET}_{0}$ values calculated using the eight empirical methods and the FAO56-PM method, and the differences exhibited spatial variability in the different agricultural zones. This highlights the need to evaluate the applicability of each method to effectively select the optimal empirical method for each agricultural zone.
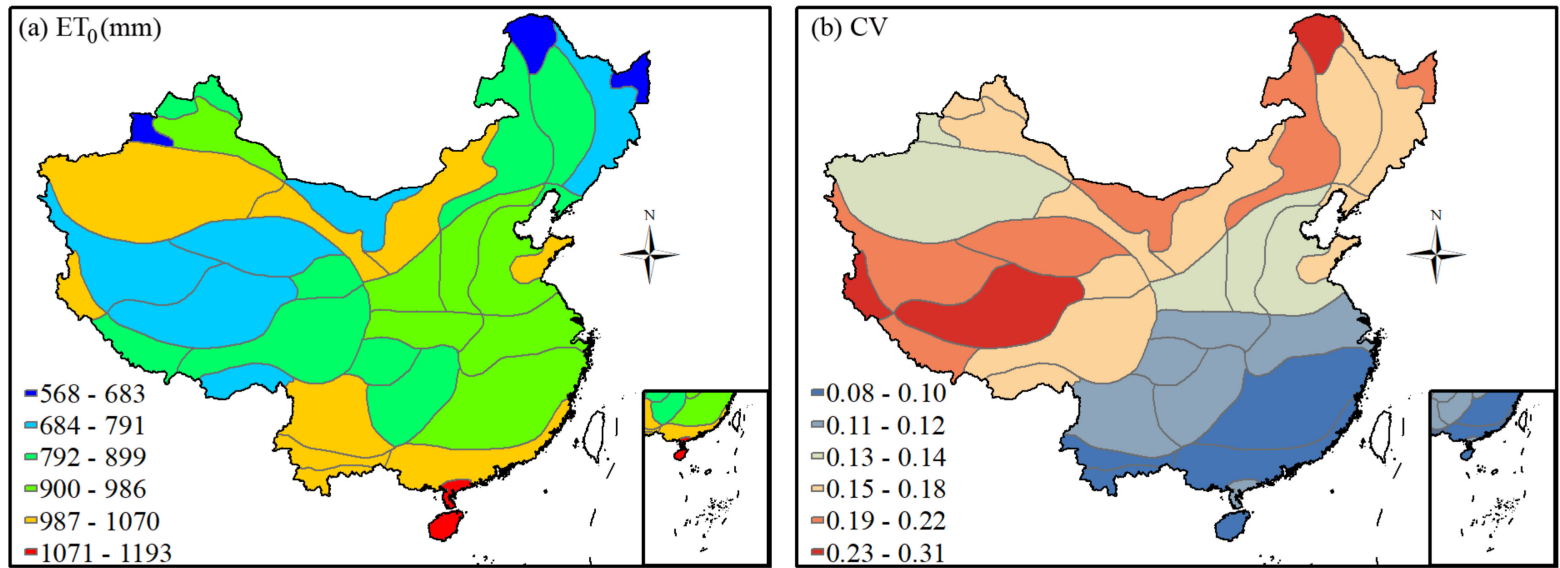

Figure 3. Spatial distribution of the annual mean reference evapotranspiration (ET0) calculated using the FAO56-PM method (a) and the coefficient of variation (CV) of the annual mean ET0 values calculated using 9 models (b) in China during the 2011-2020 period. 


\subsection{Statistical Criteria of Temperature-Based Methods}

During the study period, the mean $R^{2}$ values of the daily $\mathrm{ET}_{0}$ calculated using the FAO24-BC, H-S, and V-T methods versus the daily $\mathrm{ET}_{0}$ calculated using FAO56-PM in 36 agricultural zones were $0.95,0.85$, and 0.89 , respectively; the mean $M A E$ values were 0.79 , 0.58 , and $0.57 \mathrm{~mm} \cdot$ day $^{-1}$, respectively; the mean RMSE values were $0.96,0.76$, and 0.72 $\mathrm{mm} \cdot \mathrm{day}^{-1}$, respectively; and the mean NSE values were $0.56,0.73$, and 0.75 , respectively (Figure 4). Of the three temperature-based $\mathrm{ET}_{0}$ methods, the FAO24-BC method showed the highest $R^{2}$ in all 36 agricultural zones, followed by the H-S and V-T methods, but the other three statistical indexes showed spatial differences (Figure 5 ). The agricultural zones where the FAO24-BC method had the lowest MAE, the lowest RMSE, and the highest NSE were mainly located in Southeast China. The agricultural zones that produced the lowest $M A E$ and RMSE and highest NSE values were mainly located in (1) Southeastern China using the FAO24-BC method, (2) the Tibet Plateau and surrounding areas using the H-S method, and (3) North China and Northeastern China using the V-T method.
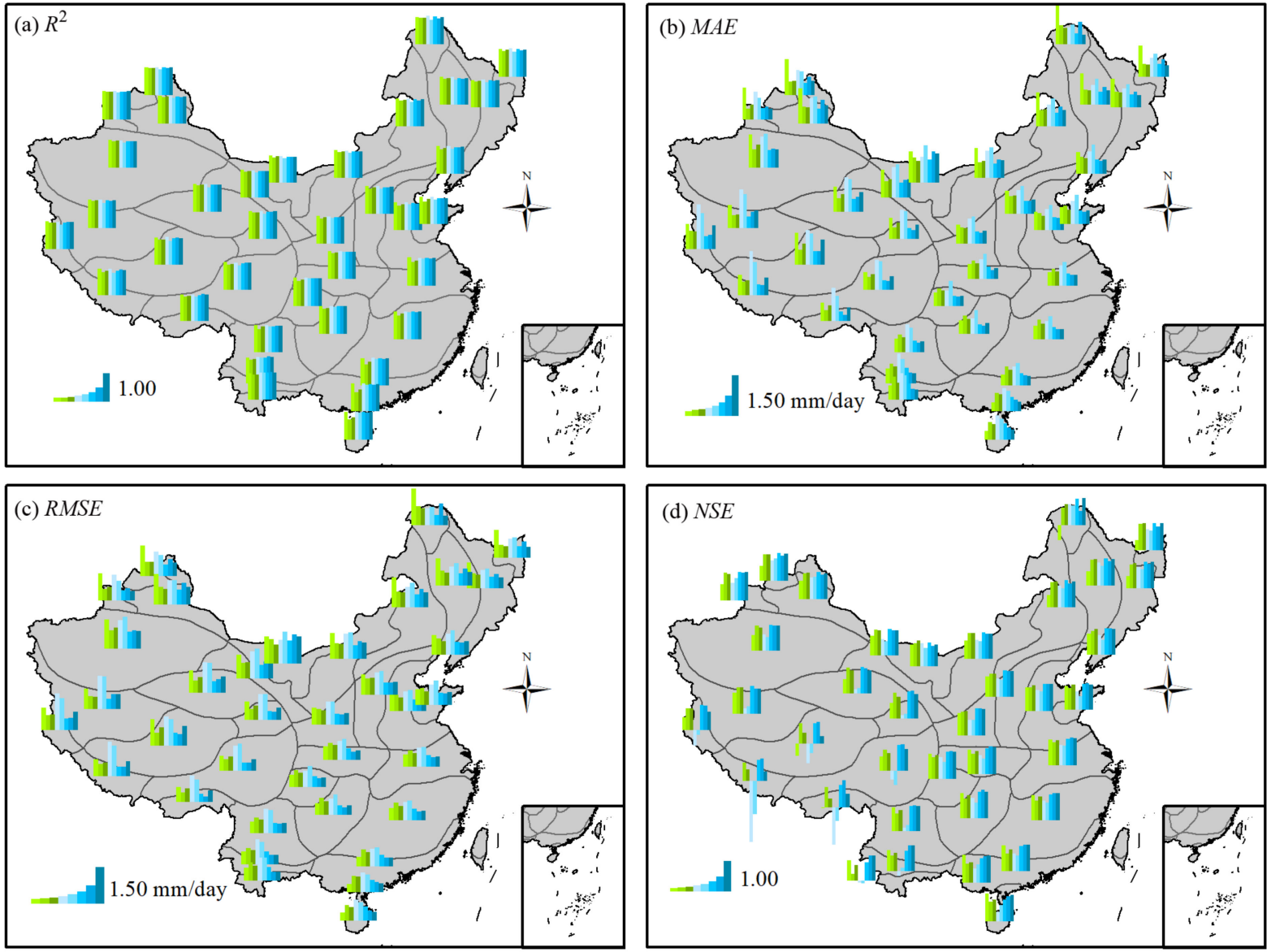

Temperature-based methods

$$
\text { FAO24-BC }
$$

(d) NSE

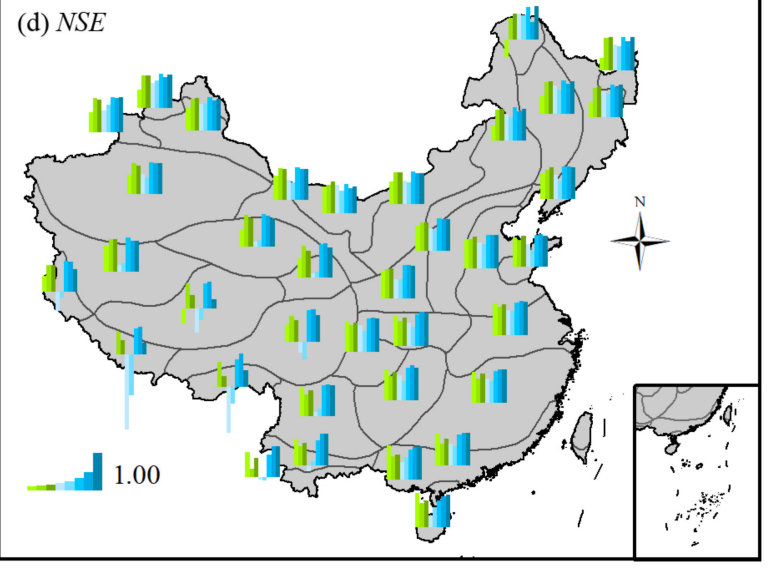

Radiation-based methods

$$
\text { FAO24-R }
$$

$$
\begin{array}{ll}
\mathrm{H}-\mathrm{S} & \mathrm{V}-\mathrm{T} \\
\mathrm{J}-\mathrm{H} & \mathrm{J}-\mathrm{R}
\end{array}
$$

Figure 4. Statistical indices of the daily reference evapotranspiration calculated using eight evaluated methods versus those calculated using the FAO56-PM method in the 36 investigated agricultural zones of China. ((a) $R^{2}$, coefficient of determination; (b) MAE, mean absolute error; (c) RMSE, root mean square error; (d) NSE, Nash-Sutcliffe efficiency.). 

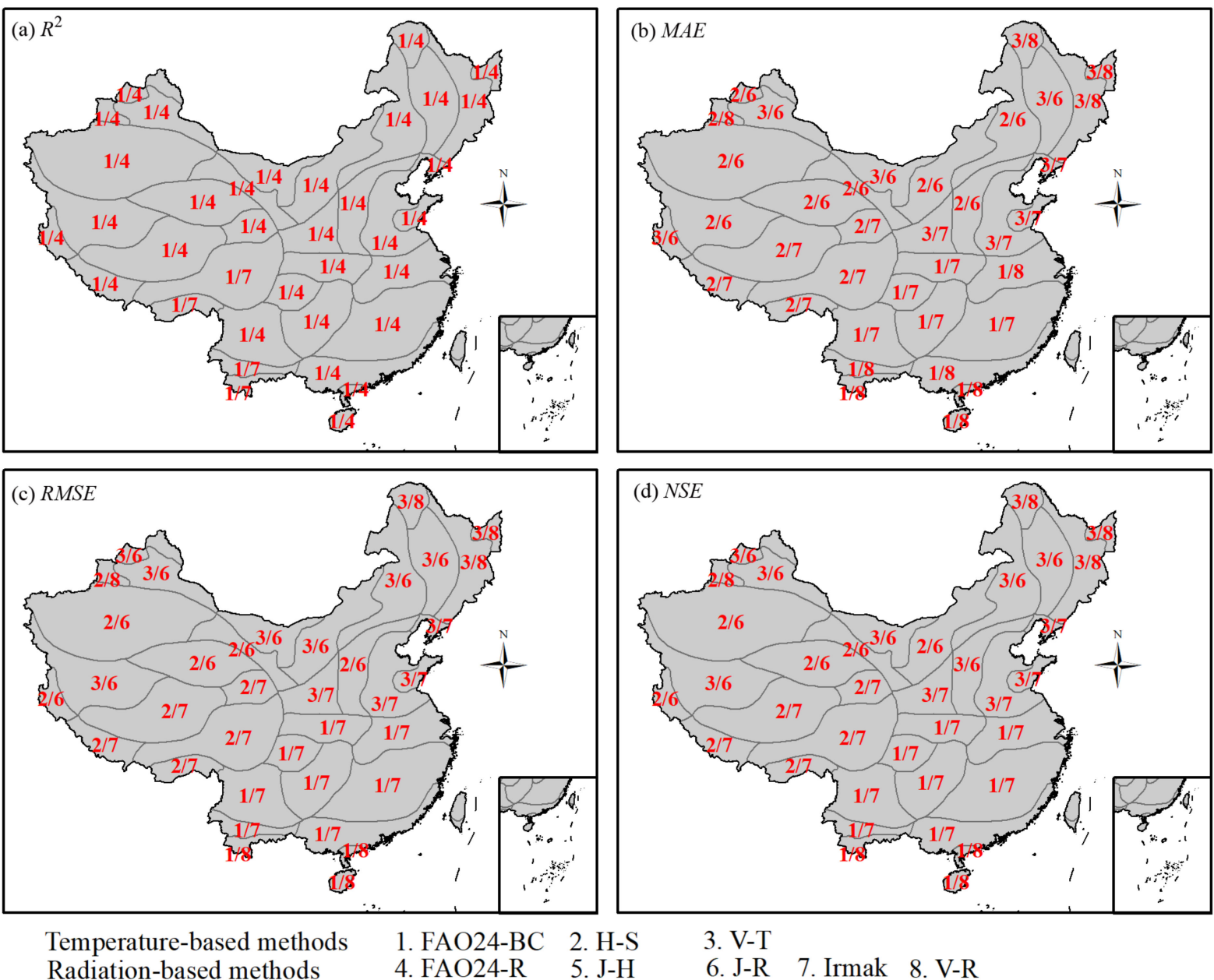

Temperature-based methods

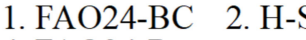

6. J-R

7. Irmak 8. V-R

Figure 5. Evaluated methods with the highest $R^{2}((\mathbf{a})$, coefficient of determination), lowest $M A E((\mathbf{b})$, mean absolute error), lowest RMSE ((c), root mean square error), and highest NSE ((d), Nash-Sutcliffe efficiency) using temperature-based/radiation-based empirical methods in 36 agricultural zones of China.

A comparison of the monthly results indicates that the NSE values obtained using the temperature-based methods and FAO56-PM method showed different seasonality features in the different agricultural zones (Figure 6). The obtained NSE values were greater than 0 in all 12 months in only three zones using the FAO24-BC method (SS-HU-2, NT-HU-2, and MP-HU-1), one zone using the H-S method (NT-HU-2), and six zones using the V-C method (NS-HU-1, NS-HU-2, MS-HU-3, MS-HU-5, SS-HU-2, and NT-HU-2). The NSE values obtained for WT-AR-1, the driest zone in China, with the smallest $A I$ (Table 1), were less than 0 in all months using the three temperature-based methods, with the exception of March using the H-S method. Similarly, the NSE values obtained for CT-HU-1, the coldest zone in China, with the lowest annual temperature (Table 1), were generally less than 0, except for April using the three temperature-based methods, as well as March using the H-S method. The daily $\mathrm{ET}_{0}$ obtained using the three temperature-based methods and FAO56-PM method showed that the colder and drier months or zones yielded smaller $R^{2}$ and larger MAE and RMSE values (Figures S1-S3). Therefore, the $\mathrm{ET}_{0}$ calculated using the temperature-based methods showed larger errors in the cold and dry months or zones. The monthly statistics showed that the V-T method performed better in South China, the FAO24-BC method performed better in North China, and the H-S method only performed better in March and April in some agricultural zones in Northeast China. 


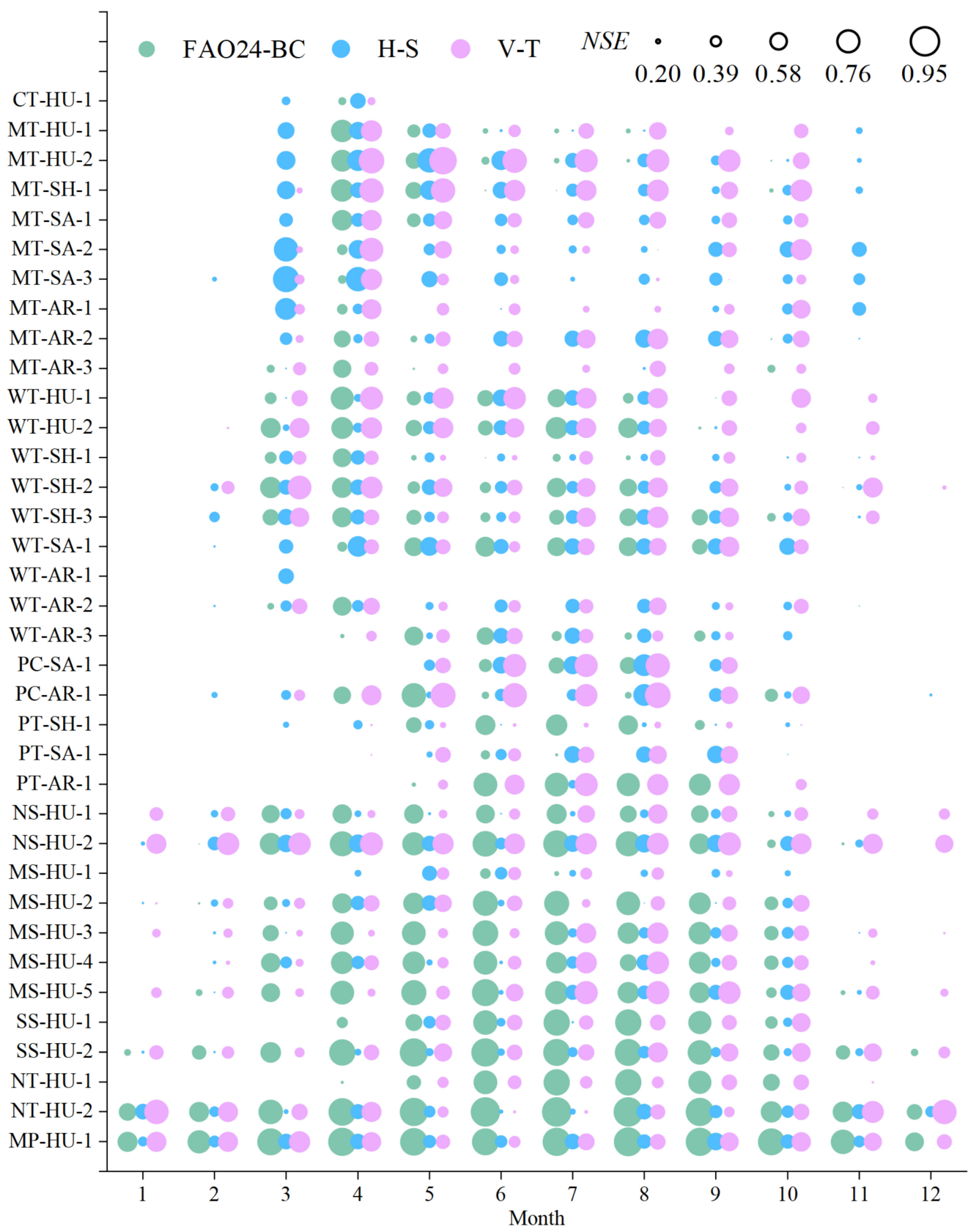

Figure 6. Monthly variation in the Nash-Sutcliffe efficiency (NSE) values obtained using the three temperature-based reference evapotranspiration methods and the FAO56-PM method in the 36 agricultural zones. NSE values less than 0 are not displayed.

\subsection{Statistical Criteria of Radiation-Based Methods}

During the study period, the mean $R^{2}$ values of the daily $\mathrm{ET}_{0}$ calculated by the FAO24$\mathrm{R}, \mathrm{J}-\mathrm{H}, \mathrm{J}-\mathrm{R}$, Irmak, and V-R methods against the daily $\mathrm{ET}_{0}$ calculated by FAO56-PM in all 36 agricultural zones were $0.95,0.88,0.92,0.92$, and 0.93 , respectively; the mean $M A E$ values were $0.91,0.95,0.46,0.49$, and $0.50 \mathrm{~mm} \cdot$ day $^{-1}$, respectively; the mean $R M S E$ values were $1.14,1.16,0.58,0.62$, and $0.63 \mathrm{~mm} \cdot$ day $^{-1}$, respectively; and the mean NSE values were $0.35,0.37,0.85,0.84$, and 0.81 , respectively (Figure 4 ). Of the five radiation-based $\mathrm{ET}_{0}$ methods, the FAO24-R method showed the highest $R^{2}$ in almost all agricultural zones, except for PT-SH-1, MS-HU-1, SS-HU-1, and NT-HU-1, where the Irmak method yielded the highest $R^{2}$ (Figure 5). The lowest MAE and RMSE and highest NSE values obtained using the five radiation-based $\mathrm{ET}_{0}$ methods showed a similar spatial distribution, and were mainly obtained in (1) North China and the northern Tibet Plateau using the J-R method, (2) 
South China and the southern Tibet Plateau using the Irmak method, and (3) the northern and mid tropical zones, three zones in Northeast China, and one zone in Northern Xinjiang using the V-R method. The FAO24-R and J-H methods did not show the lowest MAE and $R M S E$ or highest NSE values in any of the investigated agricultural zones.

Figure 7 shows the monthly variation in the NSE values obtained using the five radiationbased methods, and Figures S4-S6 show the monthly variation in the $R^{2}, M A E$, and RMSE values. Similar to the temperature-based methods, some of the NSE values obtained using the five radiation-based methods were less than 0 , particularly in arid and cold months or zones. The monthly statistics indicated that the J-R, Irmak, and V-R methods significantly outperformed the FAO24-R and J-H methods. Among these, the J-R method performed slightly better in the Tibet Plateau, and there was no significant performance difference between the Irmak and V-R methods, which performed better in the remaining regions of China.

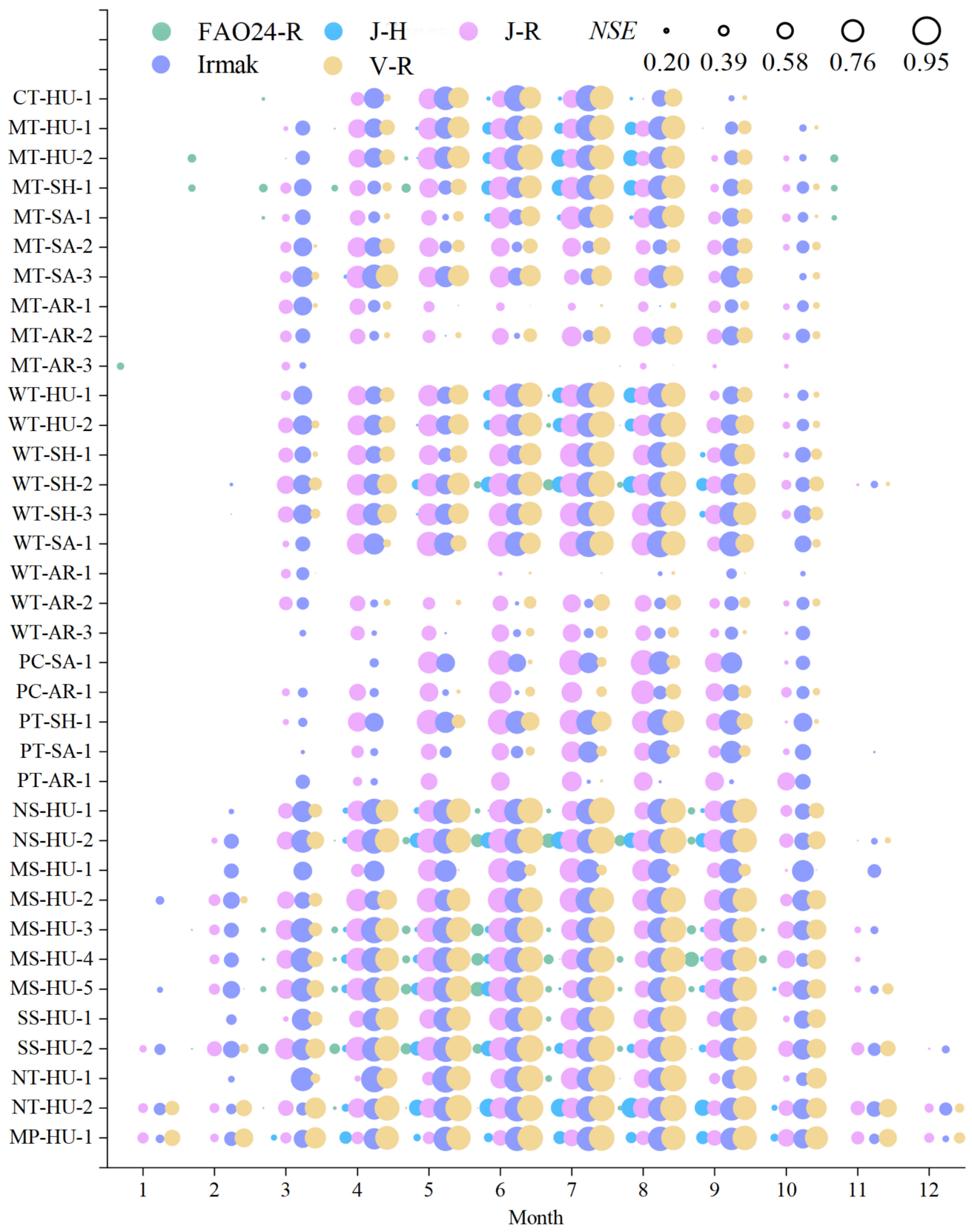

Figure 7. Monthly variation in the Nash-Sutcliffe efficiency (NSE) values obtained using the five radiation-based reference evapotranspiration methods and the FAO56-PM method in the 36 agricultural zones. NSE values less than 0 are not displayed. 


\subsection{Recommended Empirical Methods in Different Agricultural Zones}

The temperature-based and radiation-based methods for empirical $\mathrm{ET}_{0}$ calculation were ranked separately using the evaluation indexes in Equation (5). Figure 8 shows the highest and lowest performances of the temperature-based/radiation-based methods in 36 agricultural zones of China. Among the temperature-based methods, the H-S method was the optimal choice to calculate daily $\mathrm{ET}_{0}$ in the Tibet Plateau and its surrounding areas. For the remaining regions in China, the FAO24-BC and V-T methods were the most recommended methods for the south and north, respectively. In contrast, the H-S method showed the lowest performance among the three temperature-based methods in South China, and the FAO24-BC method showed the lowest performance in North China, including the Tibet Plateau, and even was not recommended for calculating the daily $\mathrm{ET}_{0}$ in CT-HU-1 and two zones in the Tibet Plateau.

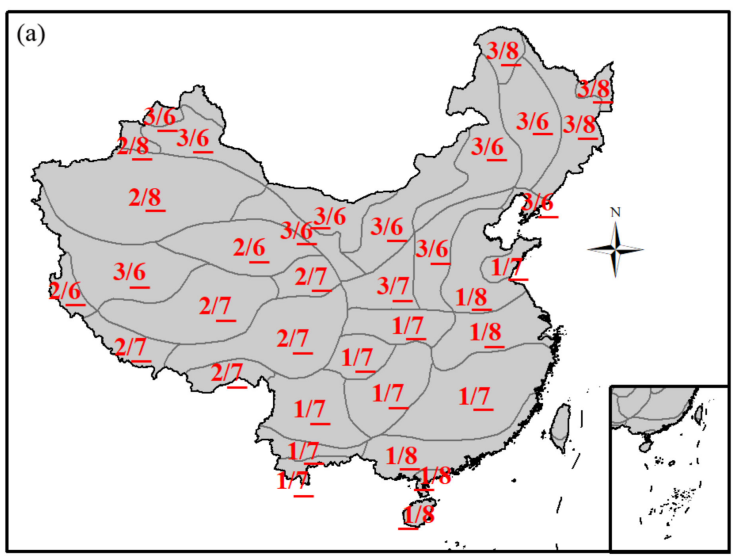

Temperature-based methods Radiation-based methods $\begin{array}{ll}\text { 1. FAO24-BC } & \text { 2. H-S } \\ \text { 4. FAO24-R } & \text { 5. J-H }\end{array}$

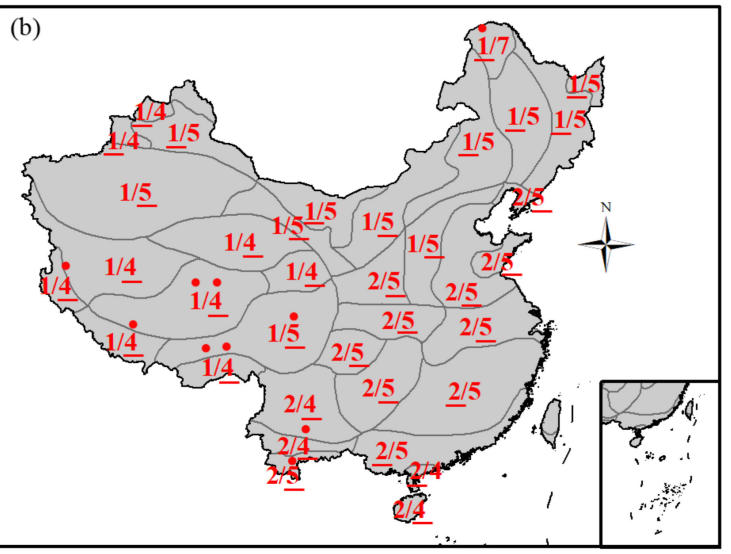

3. V-T

6. J-R 7. Irmak 8. V-R

Figure 8. Highest (a) and lowest (b) performance of the temperature-based/radiation-based reference evapotranspiration methods applied in the 36 investigated agricultural zones of China. The underscore indicates better (a) or worse (b) method of the two best/worst methods in a given zone, and the red dot indicates that the method is not recommended.

Among the radiation-based methods, the Irmak method was the optimal choice to calculate the daily $\mathrm{ET}_{0}$ in South China, including the southern Tibet Plateau, and the J-R method was the optimal choice in North China, including the northern Tibet Plateau. The $\mathrm{V}-\mathrm{R}$ method was the most recommended method in the north and mid tropical zones, two zones in Central China, three zones in Northeast China, and two zones in Xinjiang. In contrast, the J-H method showed the lowest performance among the five radiation-based methods in most zones, and even was not recommended for calculating the daily $\mathrm{ET}_{0}$ in PT-SH-1 and NT-HU-1. The FAO24-R method showed the lowest performance in the Tibet Plateau and two zones in Northern Xinjiang, and was not recommended for calculating the daily $\mathrm{ET}_{0}$ in some zones in the Tibet Plateau. The Irmak method showed the lowest performance in CT-HU-1.

A cross-comparison of the two categories showed that the highest performance of the radiation-based methods was better than that of the performance of the temperature-based methods in most zones. The recommended temperature-based methods only outperformed the radiation-based methods in three zones (MT-AR-3, NT-HU-2, and MP-HU-1). The lowest performances of the temperature-based methods were worse than those of the radiation-based methods in the northernmost and southernmost zones, and the lowest performances of the radiation-based methods were worse in the remaining zones.

The recommended temperature-based/radiation-based methods for calculating daily $\mathrm{ET}_{0}$ values in each month and zone in China are listed in Table 3. When recommending a method for each month, no empirical method was recommended for certain months in agricultural zones with extreme climatic conditions (i.e., too cold or too dry). This indicated 
that these empirical methods must be applied with caution for calculating daily $\mathrm{ET}_{0}$ values during certain months in these areas.

Table 3. The most recommended temperature-based/radiation-based reference evapotranspiration methods for each month in the 36 investigated agricultural zones of China.

\begin{tabular}{|c|c|c|c|c|c|c|c|c|c|c|c|c|}
\hline \multirow{2}{*}{ Zones } & \multicolumn{12}{|c|}{ Months } \\
\hline & 1 & 2 & 3 & 4 & 5 & 6 & 7 & 8 & 9 & 10 & 11 & 12 \\
\hline CT-HU-1 & $0 / 0$ & $0 / 0$ & $\underline{2} / 4$ & $2 / 7$ & $0 / 7$ & $0 / 7$ & $0 / 7$ & $0 / 8$ & $0 / 7$ & $2 / 0$ & $0 / 0$ & $0 / 0$ \\
\hline MT-HU-1 & $0 / 0$ & $0 / 0$ & $2 / 7$ & $\underline{1} / 7$ & $1 / 8$ & $3 / 7$ & $3 / 7$ & $3 / 7$ & $3 / 8$ & $\underline{3} / 7$ & $\underline{2} / 4$ & $0 / 0$ \\
\hline MT-HU-2 & $0 / 0$ & $0 / 4$ & $\underline{2} / 7$ & $\underline{1} / 7$ & $\underline{3} / 8$ & $\underline{3} / 8$ & $\underline{3} / 7$ & $\underline{3} / 8$ & $\underline{3} / 8$ & $\underline{3} / 7$ & $\underline{2} / 4$ & $0 / 0$ \\
\hline MT-SH-1 & $0 / 0$ & $0 / 4$ & $2 / 7$ & $\underline{1} / 6$ & $\underline{3} / 6$ & $3 / 8$ & $3 / 7$ & $3 / 7$ & $3 / 7$ & $\underline{3} / 7$ & $2 / 4$ & $0 / 0$ \\
\hline MT-SA-1 & $0 / 0$ & $0 / 4$ & $2 / 7$ & $\underline{1} / 6$ & $1 / 6$ & $3 / 6$ & $3 / 8$ & $3 / 7$ & $3 / 7$ & $\underline{3} / 7$ & $0 / 4$ & $0 / 0$ \\
\hline MT-SA-2 & $0 / 0$ & $0 / 0$ & $\underline{2} / 7$ & $\underline{3} / 6$ & $3 / 6$ & $3 / 6$ & $3 / 6$ & $2 / 7$ & $3 / 7$ & $\underline{3} / 7$ & $2 / 0$ & $0 / 0$ \\
\hline MT-SA-3 & $0 / 0$ & $2 / 0$ & $\underline{2} / 7$ & $2 / 7$ & $2 / 8$ & $2 / 8$ & $2 / 8$ & $2 / 7$ & $2 / 7$ & $\underline{3} / 7$ & $2 / 0$ & $0 / 0$ \\
\hline MT-AR-1 & $0 / 0$ & $0 / 0$ & $\underline{2} / 7$ & $\underline{3} / 6$ & $3 / 6$ & $3 / 6$ & $3 / 6$ & $3 / 6$ & $3 / 7$ & $\underline{3} / 7$ & $2 / 0$ & $0 / 0$ \\
\hline MT-AR-2 & $0 / 0$ & $0 / 0$ & $2 / 7$ & $\underline{1} / 6$ & $3 / 6$ & $3 / 6$ & $3 / 6$ & $3 / 6$ & $3 / 7$ & $\underline{3} / 7$ & $2 / 0$ & $0 / 0$ \\
\hline MT-AR-3 & $0 / 4$ & $0 / 0$ & $\underline{3} / 6$ & $1 / 0$ & $3 / 0$ & $3 / 0$ & $3 / 0$ & $\underline{3} / 6$ & $\underline{3} / 6$ & $\underline{1} / 6$ & $0 / 0$ & $0 / 0$ \\
\hline WT-HU-1 & $0 / 0$ & $0 / 0$ & $3 / 7$ & $\underline{1} / 6$ & $3 / 6$ & $1 / 8$ & $1 / 8$ & $3 / 8$ & $3 / 7$ & $\underline{3} / 7$ & $\underline{3} / 4$ & $0 / 0$ \\
\hline WT-HU-2 & $0 / 0$ & $3 / 0$ & $\underline{1} / 7$ & $\underline{1} / 7$ & $1 / 6$ & $1 / 8$ & $1 / 8$ & $1 / 8$ & $3 / 7$ & $3 / 7$ & $3 / 0$ & $0 / 0$ \\
\hline WT-SH-1 & $0 / 0$ & $0 / 0$ & $1 / 7$ & $1 / 6$ & $1 / 6$ & $2 / 8$ & $3 / 8$ & $3 / 7$ & $3 / 7$ & $3 / 7$ & $3 / 0$ & $0 / 0$ \\
\hline WT-SH-2 & $0 / 0$ & $\underline{3} / 7$ & $\underline{1} / 7$ & $\underline{1} / 7$ & $3 / 6$ & $3 / 8$ & $1 / 8$ & $1 / 8$ & $3 / 7$ & $\underline{3} / 7$ & $3 / 7$ & $3 / 0$ \\
\hline WT-SH-3 & $0 / 0$ & $\underline{2} / 7$ & $3 / 7$ & $1 / 7$ & $1 / 6$ & $1 / 8$ & $1 / 8$ & $1 / 7$ & $1 / 7$ & $3 / 7$ & $3 / 0$ & $0 / 0$ \\
\hline WT-SA-1 & $0 / 0$ & $2 / 0$ & $2 / 7$ & $2 / 7$ & $1 / 6$ & $1 / 6$ & $1 / 7$ & $1 / 7$ & $3 / 7$ & $2 / 7$ & $2 / 0$ & $0 / 0$ \\
\hline WT-AR-1 & $0 / 0$ & $0 / 0$ & $2 / 7$ & $0 / 6$ & $0 / 6$ & $0 / 6$ & $0 / 8$ & $0 / 7$ & $0 / 7$ & $0 / 7$ & $2 / 0$ & $0 / 0$ \\
\hline WT-AR-2 & $0 / 0$ & $2 / 0$ & $\underline{3} / 6$ & $\underline{1} / 6$ & $3 / 6$ & $3 / 6$ & $3 / 6$ & $3 / 6$ & $3 / 7$ & $\underline{3} / 7$ & $2 / 0$ & $0 / 0$ \\
\hline WT-AR-3 & $0 / 0$ & $0 / 0$ & $0 / 7$ & $3 / 6$ & $\underline{1} / 6$ & $1 / 6$ & $2 / 6$ & $2 / 6$ & $1 / 7$ & $2 / 7$ & $0 / 0$ & $0 / 0$ \\
\hline PC-SA-1 & $0 / 0$ & $0 / 0$ & $0 / 0$ & $0 / 7$ & $3 / 6$ & $3 / 6$ & $3 / 6$ & $3 / 6$ & $3 / 7$ & $0 / 7$ & $0 / 0$ & $0 / 0$ \\
\hline PC-AR-1 & $0 / 0$ & $2 / 0$ & $3 / 7$ & $\underline{1} / 6$ & $\underline{1} / 6$ & $3 / 6$ & $3 / 6$ & $3 / 6$ & $3 / 6$ & $\underline{3} / 7$ & $2 / 0$ & $2 / 0$ \\
\hline PT-SH-1 & $0 / 0$ & $0 / 0$ & $2 / 7$ & $2 / 7$ & $1 / 6$ & $1 / 6$ & $1 / 7$ & $1 / 7$ & $1 / 7$ & $2 / 7$ & $0 / 0$ & $0 / 0$ \\
\hline PT-SA-1 & $0 / 0$ & $0 / 0$ & $0 / 7$ & $3 / 6$ & $3 / 6$ & $1 / 6$ & $3 / 7$ & $3 / 7$ & $3 / 7$ & $2 / 7$ & $0 / 7$ & $0 / 0$ \\
\hline PT-AR-1 & $0 / 0$ & $0 / 0$ & $0 / 7$ & $0 / 6$ & $3 / 6$ & $\underline{1} / 6$ & $\underline{1} / 6$ & $\underline{1} / 6$ & $\underline{1} / 6$ & $3 / 6$ & $0 / 0$ & $0 / 0$ \\
\hline NS-HU-1 & $3 / 0$ & $\underline{3} / 7$ & $1 / 7$ & $1 / 7$ & $1 / 7$ & $1 / 7$ & $1 / 8$ & $1 / 7$ & $1 / 8$ & $3 / 7$ & $\underline{3} / 7$ & $3 / 0$ \\
\hline NS-HU-2 & $3 / 0$ & $\underline{3} / 7$ & $1 / 7$ & $1 / 7$ & $1 / 8$ & $1 / 8$ & $1 / 8$ & $1 / 8$ & $1 / 8$ & $3 / 8$ & $\underline{3} / 8$ & $3 / 0$ \\
\hline MS-HU-1 & $0 / 0$ & $0 / 7$ & $0 / 7$ & $2 / 7$ & $2 / 6$ & $1 / 6$ & $3 / 6$ & $3 / 7$ & $2 / 7$ & $2 / 7$ & $0 / 7$ & $0 / 0$ \\
\hline MS-HU-2 & $3 / 7$ & $3 / 7$ & $1 / 7$ & $1 / 6$ & $1 / 6$ & $1 / 8$ & $1 / 7$ & $1 / 7$ & $1 / 7$ & $3 / 7$ & $0 / 0$ & $0 / 0$ \\
\hline MS-HU-3 & $3 / 0$ & $3 / 7$ & $1 / 7$ & $1 / 7$ & $1 / 7$ & $1 / 8$ & $1 / 7$ & $1 / 7$ & $1 / 8$ & $1 / 7$ & $3 / 7$ & $3 / 0$ \\
\hline MS-HU-4 & $0 / 0$ & $3 / 7$ & $1 / 7$ & $1 / 7$ & $1 / 7$ & $1 / 8$ & $1 / 8$ & $3 / 8$ & $1 / 8$ & $1 / 8$ & $3 / 6$ & $0 / 0$ \\
\hline MS-HU-5 & $\underline{3} / 7$ & $3 / 7$ & $1 / 7$ & $1 / 7$ & $1 / 8$ & $1 / 8$ & $1 / 8$ & $1 / 8$ & $1 / 8$ & $3 / 7$ & $\underline{3} / 8$ & $3 / 0$ \\
\hline SS-HU-1 & $0 / 0$ & $0 / 7$ & $0 / 7$ & $1 / 8$ & $1 / 8$ & $1 / 8$ & $1 / 8$ & $1 / 8$ & $1 / 8$ & $3 / 8$ & $0 / 0$ & $0 / 0$ \\
\hline SS-HU-2 & $\underline{3} / 7$ & $1 / 7$ & $1 / 6$ & $1 / 8$ & $1 / 8$ & $1 / 8$ & $1 / 8$ & $1 / 8$ & $1 / 8$ & $1 / 7$ & $\underline{3} / 8$ & $3 / 7$ \\
\hline NT-HU-1 & $0 / 0$ & $0 / 7$ & $0 / 7$ & $1 / 7$ & $1 / 7$ & $1 / 8$ & $1 / 8$ & $1 / 8$ & $1 / 8$ & $1 / 8$ & $3 / 0$ & $0 / 0$ \\
\hline NT-HU-2 & $\underline{3} / 8$ & $\underline{1} / 8$ & $\underline{1} / 8$ & $\underline{1} / 8$ & $1 / 8$ & $1 / 8$ & $1 / 8$ & $\underline{1} / 8$ & $\underline{1} / 8$ & $\underline{1} / 8$ & $\underline{1} / 8$ & $\underline{3} / 7$ \\
\hline MP-HU-1 & $\underline{1} / 8$ & $\underline{1} / 8$ & $\underline{1} / 8$ & $\underline{1} / 8$ & $1 / 8$ & $1 / 8$ & $1 / 8$ & $\underline{1} / 8$ & $\underline{1} / 8$ & $\underline{1} / 8$ & $\underline{1} / 8$ & $\underline{1} / 8$ \\
\hline
\end{tabular}




\subsection{Calibration of the Empirical Methods in Different Agricultural Zones}

The coefficients in the empirical $\mathrm{ET}_{0}$ methods can be locally calibrated using the $\mathrm{ET}_{0}$ values from the FAO56-PM method as standard values. Table 4 shows the calibrated coefficients for the eight empirical methods in the 36 agricultural zones. Compared with the results obtained using the original methods, the $\mathrm{ET}_{0}$ values calculated using the calibrated methods better fit with those of the FAO56-PM method. The NSE values from the eight calibrated methods in 36 agricultural zones ranged from 0.64 to 0.97 , with a mean value of 0.90 , whereas the original methods ranged from -2.03 to 0.94 , with a mean value of 0.65 (Figure 9a). In all 36 agricultural zones, the NSE values obtained using the eight calibrated methods were all higher than those obtained using the original methods (Figure 9b). The $M A E$ and RMSE values obtained using the eight calibrated methods were also all lower than those obtained using the original methods (Figure S7). The statistical criteria showed that the calibrated methods with locally calibrated coefficients could be used to more accurately calculate $\mathrm{ET}_{0}$, with lower MAE and RMSE and higher NSE values. The regionally calibrated methods showed better improvements in the zones where the original methods performed poorly, such as in the Tibet Plateau. The original methods with poor performance (e.g., FAO24-R and J-H methods) showed substantial improvements using the local calibration.

Table 4. Correction coefficients, $a$ and $b$ in Equation (1), used to calibrate the empirical reference evapotranspiration methods in the 36 different agricultural zones of China.

\begin{tabular}{|c|c|c|c|c|c|c|c|c|}
\hline \multirow{2}{*}{ Zones } & \multicolumn{8}{|c|}{ Methods } \\
\hline & 1 & 2 & 3 & 4 & 5 & 6 & 7 & 8 \\
\hline CT-HU-1 & $0.46 / 1.11$ & $0.66 / 0.30$ & $0.68 / 0.35$ & $0.69 / 0.17$ & $0.77 / 0.75$ & $0.81 / 0.18$ & $0.64 / 0.90$ & $0.84 / 0.33$ \\
\hline MT-HU-1 & $0.58 / 1.03$ & $0.79 / 0.27$ & $0.78 / 0.41$ & $0.71 / 0.21$ & $0.79 / 0.95$ & $0.82 / 0.31$ & $0.80 / 0.62$ & $0.85 / 0.48$ \\
\hline MT-HU-2 & $0.56 / 1.07$ & $0.86 / 0.26$ & $0.86 / 0.35$ & $0.71 / 0.19$ & $0.87 / 0.90$ & $0.82 / 0.30$ & $0.76 / 0.70$ & $0.86 / 0.43$ \\
\hline MT-SH-1 & $0.59 / 1.06$ & $0.89 / 0.27$ & $0.85 / 0.39$ & $0.74 / 0.21$ & $0.85 / 1.00$ & $0.88 / 0.32$ & $0.86 / 0.67$ & $0.91 / 0.49$ \\
\hline MT-SA-1 & $0.59 / 1.16$ & $0.87 / 0.40$ & $0.80 / 0.53$ & $0.74 / 0.20$ & $0.77 / 1.13$ & $0.92 / 0.36$ & $0.90 / 0.72$ & $0.93 / 0.58$ \\
\hline MT-SA-2 & $0.60 / 0.94$ & $0.98 / 0.17$ & $0.85 / 0.34$ & $0.73 / 0.15$ & $0.81 / 0.88$ & $0.95 / 0.19$ & $0.95 / 0.64$ & $0.98 / 0.41$ \\
\hline MT-SA-3 & $0.62 / 0.82$ & $0.93 / 0.04$ & $0.81 / 0.32$ & $0.70 / 0.09$ & $0.73 / 0.78$ & $0.90 / 0.11$ & $0.93 / 0.42$ & $0.92 / 0.35$ \\
\hline MT-AR-1 & $0.64 / 0.95$ & $1.06 / 0.19$ & $0.90 / 0.35$ & $0.76 / 0.14$ & $0.81 / 0.99$ & $1.00 / 0.24$ & $1.03 / 0.64$ & $1.04 / 0.44$ \\
\hline MT-AR-2 & $0.64 / 1.09$ & $0.96 / 0.34$ & $0.83 / 0.55$ & $0.74 / 0.15$ & $0.70 / 1.25$ & $0.97 / 0.30$ & $1.04 / 0.45$ & $0.96 / 0.62$ \\
\hline MT-AR-3 & $0.68 / 1.18$ & $1.10 / 0.44$ & $0.91 / 0.65$ & $0.81 / 0.17$ & $0.74 / 1.55$ & $1.09 / 0.41$ & $1.24 / 0.44$ & $1.09 / 0.77$ \\
\hline WT-HU-1 & $0.66 / 0.89$ & $0.92 / 0.33$ & $0.89 / 0.43$ & $0.72 / 0.28$ & $0.83 / 1.22$ & $0.83 / 0.40$ & $0.92 / 0.35$ & $0.86 / 0.63$ \\
\hline WT-HU-2 & $0.72 / 0.72$ & $0.93 / 0.35$ & $0.96 / 0.19$ & $0.72 / 0.31$ & $0.8 / 1.29$ & $0.86 / 0.31$ & $0.98 / 0.15$ & $0.88 / 0.59$ \\
\hline WT-SH-1 & $0.66 / 0.87$ & $0.83 / 0.30$ & $0.78 / 0.43$ & $0.71 / 0.28$ & $0.67 / 1.21$ & $0.88 / 0.30$ & $0.98 / 0.32$ & $0.88 / 0.60$ \\
\hline WT-SH-2 & $0.72 / 0.66$ & $0.89 / 0.17$ & $0.90 / 0.10$ & $0.73 / 0.30$ & $0.74 / 1.18$ & $0.89 / 0.21$ & $1.01 / 0.08$ & $0.89 / 0.47$ \\
\hline WT-SH-3 & $0.69 / 0.81$ & $0.87 / 0.21$ & $0.83 / 0.30$ & $0.69 / 0.28$ & $0.65 / 1.19$ & $0.87 / 0.26$ & $0.99 / 0.18$ & $0.87 / 0.58$ \\
\hline WT-SA-1 & $0.66 / 1.07$ & $0.84 / 0.29$ & $0.71 / 0.66$ & $0.65 / 0.16$ & $0.54 / 1.20$ & $0.85 / 0.29$ & $0.92 / 0.38$ & $0.85 / 0.71$ \\
\hline WT-AR-1 & $0.64 / 0.83$ & $0.93 / 0.21$ & $0.80 / 0.38$ & $0.74 / 0.13$ & $0.64 / 1.17$ & $0.93 / 0.27$ & $1.07 / 0.29$ & $0.96 / 0.49$ \\
\hline WT-AR-2 & $0.65 / 1.03$ & $0.95 / 0.33$ & $0.80 / 0.62$ & $0.72 / 0.15$ & $0.62 / 1.35$ & $0.96 / 0.29$ & $1.08 / 0.33$ & $0.94 / 0.68$ \\
\hline WT-AR-3 & $0.64 / 1.27$ & $0.92 / 0.43$ & $0.74 / 0.81$ & $0.66 / 0.13$ & $0.55 / 1.37$ & $0.90 / 0.43$ & $0.99 / 0.49$ & $0.91 / 0.83$ \\
\hline PC-SA-1 & $0.64 / 1.54$ & $0.86 / 0.68$ & $0.69 / 1.15$ & $0.60 / 0.21$ & $0.50 / 1.46$ & $0.75 / 0.83$ & $0.86 / 0.71$ & $0.83 / 1.13$ \\
\hline PC-AR-1 & $0.67 / 1.13$ & $1.04 / 0.26$ & $0.83 / 0.62$ & $0.66 / 0.11$ & $0.54 / 1.33$ & $0.94 / 0.37$ & $1.02 / 0.49$ & $0.97 / 0.66$ \\
\hline PT-SH-1 & $0.71 / 1.03$ & $0.79 / 0.37$ & $0.70 / 0.64$ & $0.64 / 0.20$ & $0.47 / 1.31$ & $0.85 / 0.28$ & $0.94 / 0.35$ & $0.86 / 0.71$ \\
\hline PT-SA-1 & $0.70 / 1.29$ & $0.86 / 0.66$ & $0.73 / 0.98$ & $0.61 / 0.15$ & $0.48 / 1.61$ & $0.80 / 0.53$ & $0.95 / 0.4$ & $0.82 / 0.97$ \\
\hline PT-AR-1 & $0.66 / 1.51$ & $1.02 / 0.59$ & $0.79 / 1.06$ & $0.64 / 0.07$ & $0.48 / 1.60$ & $0.86 / 0.71$ & $1.02 / 0.45$ & $0.91 / 1.05$ \\
\hline
\end{tabular}


Table 4. Cont.

\begin{tabular}{|c|c|c|c|c|c|c|c|c|}
\hline \multirow{2}{*}{ Zones } & \multicolumn{8}{|c|}{ Methods } \\
\hline & 1 & 2 & 3 & 4 & 5 & 6 & 7 & 8 \\
\hline NS-HU-1 & $0.72 / 0.63$ & $0.81 / 0.09$ & $0.86 /-0.04$ & $0.69 / 0.39$ & $0.62 / 1.13$ & $0.83 / 0.24$ & $0.98 / 0.01$ & $0.84 / 0.51$ \\
\hline NS-HU-2 & $0.77 / 0.56$ & $0.93 /-0.02$ & $1.01 /-0.19$ & $0.73 / 0.31$ & $0.73 / 1.14$ & $0.86 / 0.16$ & $1.04 /-0.20$ & $0.87 / 0.42$ \\
\hline MS-HU-1 & $0.71 / 1.06$ & $0.84 / 0.35$ & $0.71 / 0.72$ & $0.64 / 0.12$ & $0.55 / 1.28$ & $0.84 / 0.26$ & $0.97 / 0.17$ & $0.84 / 0.74$ \\
\hline MS-HU-2 & $0.78 / 0.62$ & $0.9 /-0.04$ & $0.91 /-0.10$ & $0.67 / 0.32$ & $0.56 / 1.23$ & $0.91 / 0.07$ & $1.13 /-0.40$ & $0.91 / 0.37$ \\
\hline MS-HU-3 & $0.74 / 0.68$ & $0.81 / 0.04$ & $0.88 /-0.12$ & $0.69 / 0.43$ & $0.61 / 1.10$ & $0.82 / 0.25$ & $0.97 /-0.04$ & $0.81 / 0.58$ \\
\hline MS-HU-4 & $0.75 / 0.61$ & $0.85 /-0.03$ & $0.91 /-0.16$ & $0.71 / 0.41$ & $0.65 / 1.10$ & $0.83 / 0.25$ & $1.04 /-0.22$ & $0.85 / 0.50$ \\
\hline MS-HU-5 & $0.75 / 0.62$ & $0.88 /-0.08$ & $0.98 /-0.31$ & $0.71 / 0.39$ & $0.65 / 1.14$ & $0.82 / 0.23$ & $1.04 /-0.28$ & $0.84 / 0.46$ \\
\hline SS-HU-1 & $0.75 / 0.58$ & $0.93 /-0.26$ & $0.91 /-0.13$ & $0.67 / 0.39$ & $0.56 / 1.20$ & $0.86 / 0.09$ & $1.20 /-0.88$ & $0.90 / 0.23$ \\
\hline SS-HU-2 & $0.79 / 0.63$ & $0.93 / 0.01$ & $1.14 /-0.61$ & $0.69 / 0.56$ & $0.65 / 1.33$ & $0.80 / 0.42$ & $1.05 /-0.37$ & $0.84 / 0.53$ \\
\hline NT-HU-1 & $0.73 / 0.65$ & $0.86 /-0.20$ & $0.86 /-0.02$ & $0.66 / 0.43$ & $0.54 / 1.14$ & $0.82 / 0.11$ & $1.15 /-0.88$ & $0.84 / 0.29$ \\
\hline NT-HU-2 & $0.84 / 0.55$ & $1.05 /-0.13$ & $1.33 /-0.81$ & $0.69 / 0.55$ & $0.70 / 1.34$ & $0.79 / 0.41$ & $1.07 /-0.51$ & $0.85 / 0.45$ \\
\hline MP-HU-1 & $0.85 / 0.52$ & $0.98 /-0.03$ & $1.21 /-0.56$ & $0.68 / 0.55$ & $0.65 / 1.31$ & $0.77 / 0.41$ & $1.12 /-0.75$ & $0.84 / 0.41$ \\
\hline
\end{tabular}

Note. 1. FAO24-BC; 2. H-S; 3. V-T; 4. FAO24-R; 5. J-H; 6. J-R; 7. Irmak; 8. V-R.

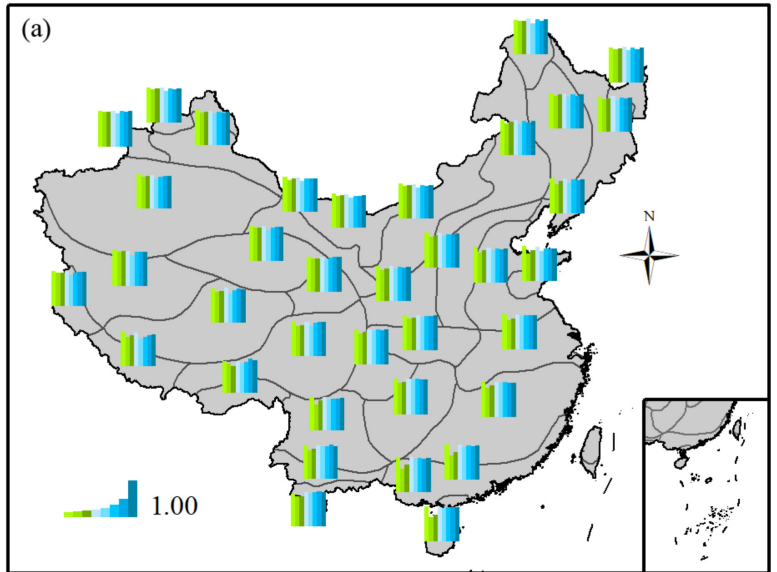

Temperature-based methods Radiation-based methods

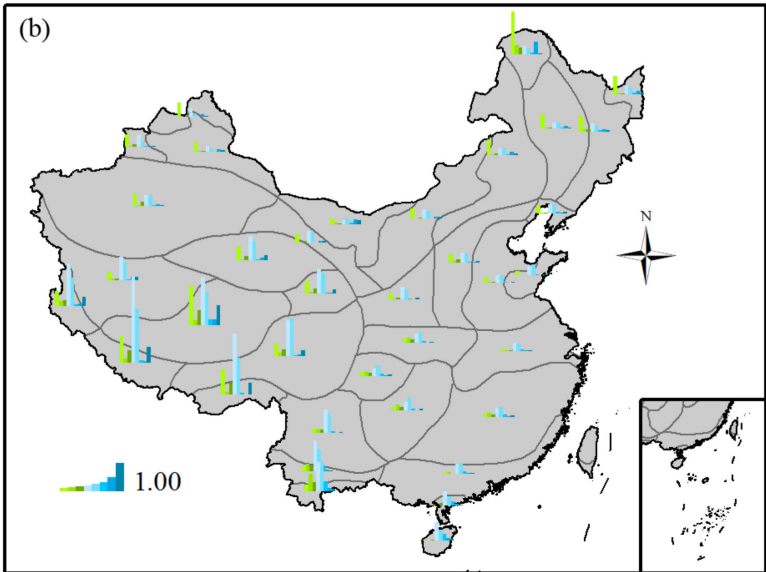

$\begin{array}{ll}\mathrm{H}-\mathrm{S} & \mathrm{V}-\mathrm{T} \\ \mathrm{J}-\mathrm{H} & \mathrm{J}-\mathrm{R}\end{array} \mathrm{Irmak} \quad \mathrm{V}-\mathrm{R}$

Figure 9. Nash-Sutcliffe efficiency (NSE) values obtained from the daily reference evapotranspiration calculated using the eight calibrated methods versus daily reference evapotranspiration calculated using the FAO56-PM method (a); the difference between the NSE values obtained using the calibrated methods and the original methods (b) in 36 agricultural zones of China.

\section{Discussion}

\subsection{Comparison with Previous Studies}

Several studies have evaluated the performance of different empirical $\mathrm{ET}_{0}$ methods in specific climatic conditions to select the most suitable empirical method when data availability is limited. Tabari et al. [26] evaluated $31 \mathrm{ET}_{0}$ methods under humid conditions in Northern Iran and found that the FAO24-BC method exhibited the best performance among the temperature-based methods. Mallikarjuna et al. [52] reported that the FAO24-BC method showed more accurate $\mathrm{ET}_{0}$ values than the $\mathrm{H}-\mathrm{S}$ method under humid conditions in Southern India. Pandey et al. [25] also considered the FAO24-BC method to be a more suitable temperature-based empirical method than the H-S method for humid Northeastern India. In contrast, the H-S method outperformed the FAO24-BC method in arid regions, such as Doha airport in Qatar [53], and arid and semi-arid areas in Iran [54]. The results of this study are consistent with the previous findings: the FAO24-BC method outperformed 
the H-S method in the humid regions of South China, and the H-S method outperformed the FAO24-BC method in the arid regions of North China. In this study, the H-S method was the most suitable temperature-based method in the Tibet Plateau, and other studies also confirmed that this method had sufficiently high accuracy in mountainous areas of China [55] and Italy [56]. Some studies also concluded that the H-S method seems to be inaccurate in particularly windy areas $[57,58]$.

Among the radiation-based methods, Tabari et al. [26] reported that the Irmak method performed better than the J-H method under humid conditions in Northern Iran and in other humid regions. Similar results were reported by Pandey et al. [25] in Northeastern India and by Islam and Alam [50] in Bangladesh. The FAO24-R method has been shown to outperform the J-R method in the subhumid valley rangeland of the Eastern Himalayas [59], as well as the J-H method under tropical semi-humid conditions in a Brazilian savannah [24]. The results presented here are consistent with these previous findings. The Irmak method is the recommended radiation-based method in many regions of China, such as South China and the Tibet Plateau, and the J-H method is the least recommended radiation-based method in most of the investigated areas.

\subsection{Selection of Reliable Empirical Methods Based on Climatic Conditions}

This study and other published reports all concluded that the optimal temperaturebased/radiation-based method is sensitive to climate conditions in different regions. Figure 10a,c show the optimal temperature-based/radiation-based method for different annual mean air temperatures and $A I$ values in the 36 investigated agricultural zones. The results show that the FAO24-BC method is the optimal temperature-based method for zones with an annual mean temperature above $12{ }^{\circ} \mathrm{C}$ and an $A I$ value larger than 0.5 , whereas the $\mathrm{H}-\mathrm{S}$ and $\mathrm{V}-\mathrm{T}$ methods are the optimal choices for zones with an annual mean temperature below $12{ }^{\circ} \mathrm{C}$ and an $A I$ value smaller than 0.5 . For the radiation-based methods, the J-R method is the most recommended for zones with an annual mean temperature below $12{ }^{\circ} \mathrm{C}$ and an $A I$ value smaller than 0.75 , and the Irmak and V-R methods are suitable for a wider range of climate conditions. The FAO24- $\mathrm{R}$ and J-H methods are not optimal methods in any agricultural zone. The relationship between the optimal methods and the climatic conditions based on 823 meteorological stations in China showed similar results based on the agricultural zones (Figure 10b,d). The results presented here can therefore provide useful guidelines for selecting reliable empirical methods in other regions.
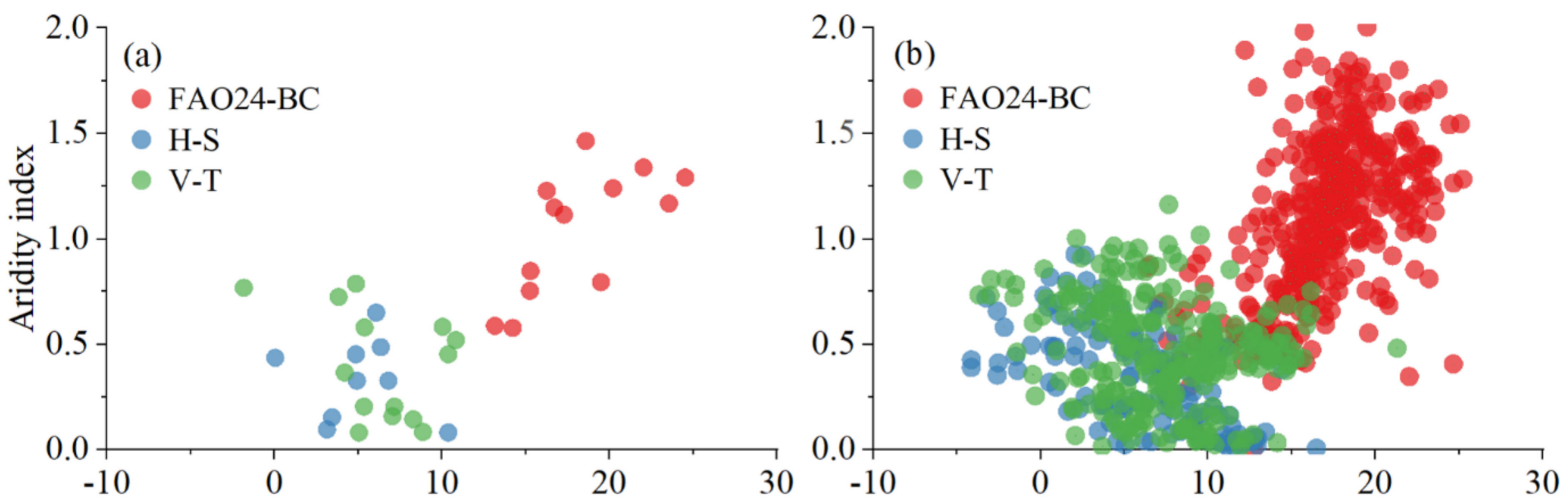

Figure 10. Cont. 

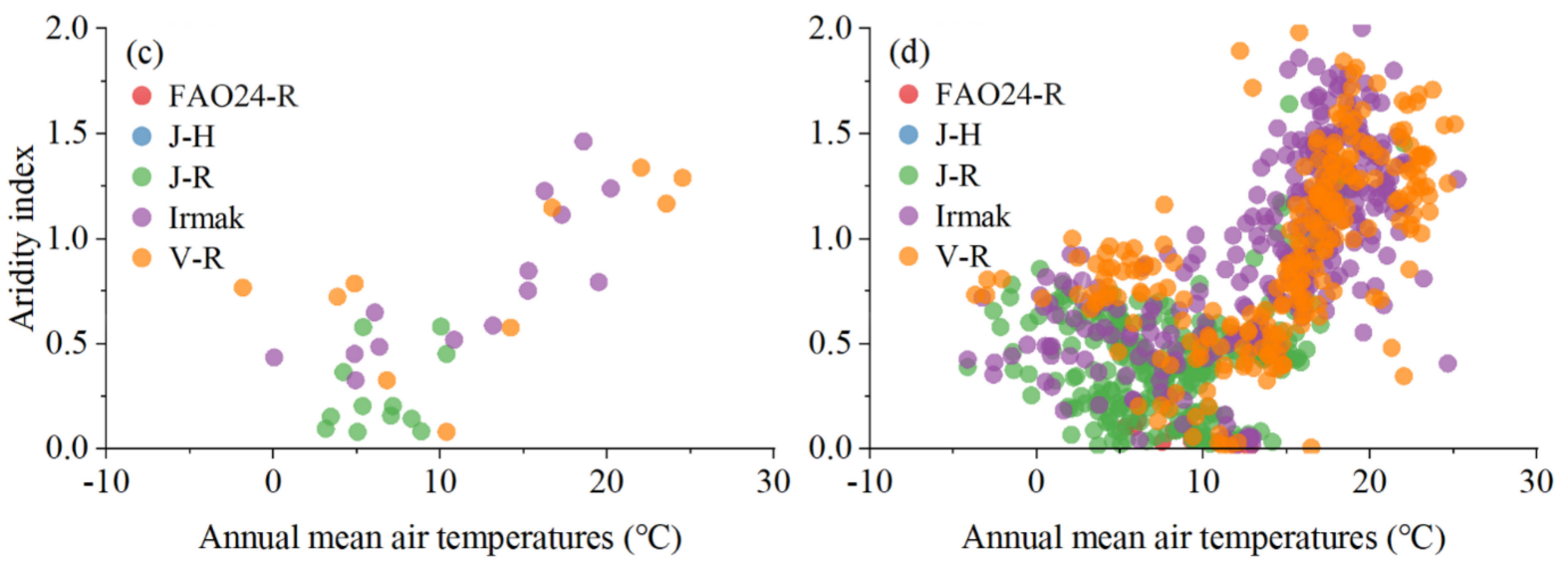

Figure 10. Optimal temperature-based $(\mathbf{a}, \mathbf{b})$ and radiation-based methods $(\mathbf{c}, \mathbf{d})$ for the different annual mean air temperatures and aridity index values in the 36 agricultural zones $(\mathbf{a}, \mathbf{c})$ and 823 meteorological stations $(\mathbf{b}, \mathbf{d})$ of China.

\section{Conclusions}

Reference evapotranspiration $\left(\mathrm{ET}_{0}\right)$ values calculated using the FA056-PM method were applied to evaluate eight alternative methods for calculating daily $\mathrm{ET}_{0}$ values, including three temperature-based and five radiation-based, in 36 agricultural zones in China. Both within the 36 agricultural zones and across China as a whole, the area-averaged annual $\mathrm{ET}_{0}$ values showed large disparities between models, and the annual mean $\mathrm{ET}_{0}$ values across China calculated using the nine total methods yielded a $C V$ value of 0.14 . The annual mean $\mathrm{ET}_{0}$ values calculated using the different methods showed minor variability in South China, but large variability in Northeast China and the Tibet Plateau.

The H-S method was determined to be the optimal temperature-based method to calculate daily $\mathrm{ET}_{0}$ in the agricultural zones in the Tibet Plateau and its surrounding areas. For the remaining regions of China, the FAO24-BC method was the recommended temperature-based method in the south and the V-T method was the recommended method in the north. The Irmak method was the optimal radiation-based method in South China, including the southern Tibet Plateau, whereas the J-R method was the optimal choice in North China, including the northern Tibet Plateau. The V-R method was the recommended method in the north and mid tropical zones and some agricultural zones in Xinjiang and Northeast China. The J-H method was the least recommended radiation-based method in most zones in China. The empirical methods based on temperature/radiation were also recommended separately for each month in the investigated agricultural zones. No empirical method was recommended for certain months in some agricultural zones, owing to extreme climate conditions.

The empirical methods were locally calibrated using $\mathrm{ET}_{0}$ values calculated using the FAO56-PM method, which improved the model accuracy. The relationship between the optimal methods and climatic conditions showed that the most reliable empirical method could be selected according to the local climatic conditions.

This study makes a crucial contribution to the study of $\mathrm{ET}_{0}$ in different agricultural zones in China (especially when the meteorological data requirements cannot be fully met) and provides valuable information for policymakers, irrigation managers, and farmers for estimating the irrigation water demand and efficient use of water resources in different agricultural zones. The outcomes of this study also provide important guidance for the selection of reliable empirical $\mathrm{ET}_{0}$ methods based on local climatic conditions in regions outside of the study area.

Supplementary Materials: The following are available online at https: / www.mdpi.com/article / 10.3390/agronomy12010031/s1, Material S1: The procedure to estimate wind speed at $2 \mathrm{~m}$ height and radiations. Material S2: The equation of the Penman method. Figure S1: Monthly variation of 
the coefficient of determination $\left(R^{2}\right)$ values obtained using the three temperature-based reference evapotranspiration methods and the FAO56-PM method in the 36 agricultural zones. Figure S2: Monthly variation of the mean absolute error $(M A E, \mathrm{~mm} \cdot$ day -1$)$ values obtained using the three temperature-based reference evapotranspiration methods and the FAO56-PM method in the 36 agricultural zones. Figure S3: Monthly variation of the root mean square error $\left(R M S E, \mathrm{~mm}^{\prime} \mathrm{day}^{-1}\right)$ values obtained using the three temperature-based reference evapotranspiration methods and the FAO56-PM method in the 36 agricultural zones. Figure S4: Monthly variation of the coefficient of determination $\left(R^{2}\right)$ values obtained using the five radiation-based reference evapotranspiration methods and the FAO56-PM method in the 36 agricultural zones. Figure S5: Monthly variation of the mean absolute error $\left(M A E, \mathrm{~mm} \cdot \mathrm{day}^{-1}\right)$ values obtained using the five radiation-based reference evapotranspiration methods and the FAO56-PM method in the 36 agricultural zones. Figure S6: Monthly variation of the mean root mean square error $\left(R M S E, \mathrm{~mm} \cdot \mathrm{day}^{-1}\right)$ values obtained using the five radiation-based reference evapotranspiration methods and the FAO56-PM method in the 36 agricultural zones. Figure S7: Mean absolute error MAE (a) and root mean square error RMSE (b) obtained from the daily reference evapotranspiration calculated using the eight calibrated methods versus daily reference evapotranspiration calculated using the FAO56-PM method, the difference between the MAE (c) and RMSE (d) from the original methods minus those from the calibrated methods in 36 agricultural zones of China.

Author Contributions: Conceptualization, Y.Y. and R.C.; methodology, Y.Y. and R.C.; validation, Y.Y., R.C., C.H., Z.L. and X.W.; formal analysis, Y.Y. and R.C.; data curation, C.H., Z.L. and X.W.; writing-original draft preparation, Y.Y. and R.C. All authors have read and agreed to the published version of the manuscript.

Funding: This work was carried out with financial support from the National Key Research and Development Project (2019YFC1510505), the Joint Grant from Chinese Academy of Sciences-People's Government of Qinghai Province on Sanjiangyuan National Park (LHZX-2020-11), and the Sciences and Technology Plan Project of Gansu Province (21JR7RA056).

Institutional Review Board Statement: Not applicable.

Informed Consent Statement: Not applicable.

Data Availability Statement: Not applicable.

Conflicts of Interest: The authors declare no conflict of interest.

\section{References}

1. Jung, M.; Reichstein, M.; Ciais, P.; Seneviratne, S.I.; Sheffield, J.; Goulden, M.L.; Bonan, G.; Cescatti, A.; Chen, J.; de Jeu, R.; et al. Recent decline in the global land evapotranspiration trend due to limited moisture supply. Nature 2010, 467, 951-954. [CrossRef] [PubMed]

2. Xiang, K.; Li, Y.; Horton, R.; Feng, H. Similarity and difference of potential evapotranspiration and reference crop evapotranspiration-A review. Agric. Water Manag. 2020, 232, 106043. [CrossRef]

3. Fan, J.; Yue, W.; Wu, L.; Zhang, F.; Cai, H.; Wang, X.; Lu, X.; Xiang, Y. Evaluation of SVM, ELM and four tree-based ensemble models for predicting daily reference evapotranspiration using limited meteorological data in different climates of China. Agric. For. Meteorol. 2018, 263, 225-241. [CrossRef]

4. Kim, D.; Chun, J.A.; Ko, J. A hybrid approach combining the FAO-56 method and the complementary principle for predicting daily evapotranspiration on a rainfed crop field. J. Hydrol. 2019, 577, 123941. [CrossRef]

5. McMahon, T.A.; Finlayson, B.L.; Peel, M.C. Historical developments of models for estimating evaporation using standard meteorological data. Wires Water 2016, 3, 788-818. [CrossRef]

6. De Bruin, H.A.R.; Trigo, I.F.; Bosveld, F.C.; Meirink, J.F. A thermodynamically based model for actual evapotranspiration of an extensive grass field close to FAO reference, suitable for remote sensing application. J. Hydrometeorol. 2016, 17, 1373-1382. [CrossRef]

7. Wang, J.; Wang, J.L.; Zhao, C.X.; McGiffen, M.E.; Liu, J.B.; Wang, G.D. Assessing the performance of two models on calculating maize actual evapotranspiration in a semi-humid and drought-prone region of China. Theor. Appl. Climatol. 2018, 131, 1147-1156. [CrossRef]

8. Martel, M.; Glenn, A.; Wilson, H.; Kröbel, R. Simulation of actual evapotranspiration from agricultural landscapes in the Canadian Prairies. J. Hydrol. Reg. Stud. 2018, 15, 105-118. [CrossRef]

9. Allen, R.G.; Pereira, L.S.; Raes, D.; Smith, M. Crop Evapotranspiration-Guidelines for Computing Crop Water Requirements; FAO Irrigation and Drainage Paper No. 56; FAO: Rome, Italy, 1998. 
10. Kisi, O.; Alizamir, M. Modelling reference evapotranspiration using a new wavelet conjunction heuristic method: Wavelet extreme learning machine vs wavelet neural networks. Agric. For. Meteorol. 2018, 263, 41-48. [CrossRef]

11. Martí, P.; Zarzo, M. Multivariate statistical monitoring of ETo: A new approach for estimation in nearby locations using geographical inputs. Agric. For. Meteorol. 2012, 152, 125-134. [CrossRef]

12. Xu, S.; Yu, Z.; Yang, C.; Ji, X.; Zhang, K. Trends in evapotranspiration and their responses to climate change and vegetation greening over the upper reaches of the Yellow River Basin. Agric. For. Meteorol. 2018, 263, 118-129. [CrossRef]

13. Lu, Y.; Cai, H.; Jiang, T.; Sun, S.; Wang, Y.; Zhao, J.; Yu, X.; Sun, J. Assessment of global drought propensity and its impacts on agricultural water use in future climate scenarios. Agric. For. Meteorol. 2019, 278, 107623. [CrossRef]

14. Doorenbos, J.; Pruitt, W.O. Guidelines for Predicting Crop Water Requirements, 2nd ed.; FAO Irrigation and Drainage Paper No. 24; FAO: Roma, Italy, 1977.

15. Ahmadi, S.H.; Javanbakht, Z. Assessing the physical and empirical reference evapotranspiration (ETo) models and time series analyses of the influencing weather variables on ETo in a semi-arid area. J. Environ. Manag. 2020, 276, 111278. [CrossRef]

16. Pereira, L.S.; Allen, R.G.; Smith, M.; Raes, D. Crop evapotranspiration estimation with FAO56: Past and future. Agric. Water Manag. 2015, 147, 4-20. [CrossRef]

17. Shiri, J. Evaluation of FAO56-PM, empirical, semi-empirical and gene expression programming approaches for estimating daily reference evapotranspiration in hyper-arid regions of Iran. Agric. Water Manag. 2017, 188, 101-114. [CrossRef]

18. Kashyap, P.S.; Panda, R.K. Evaluation of evapotranspiration estimation methods and development of crop-coefficients for potato crop in a sub-humid region. Agric. Water Manag. 2001, 50, 9-25. [CrossRef]

19. Liu, X.; Xu, C.; Zhong, X.; Li, Y.; Yuan, X.; Cao, J. Comparison of 16 models for reference crop evapotranspiration against weighing lysimeter measurement. Agric. Water Manag. 2017, 184, 145-155. [CrossRef]

20. Bourletsikas, A.; Argyrokastritis, I.; Proutsos, N. Comparative evaluation of 24 reference evapotranspiration equations applied on an evergreen-broadleaved forest. Hydrol. Res. 2018, 49, 1028-1041. [CrossRef]

21. Awal, R.; Habibi, H.; Fares, A.; Deb, S. Estimating reference crop evapotranspiration under limited climate data in West Texas. J. Hydrol. Reg. Stud. 2020, 28, 100677. [CrossRef]

22. Moratiel, R.; Bravo, R.; Saa, A.; Tarquis, A.M.; Almorox, J. Estimation of evapotranspiration by the Food and Agricultural Organization of the United Nations (FAO) Penman-Monteith temperature (PMT) and Hargreaves-Samani (HS) models under temporal and spatial criteria-A case study in Duero basin (Spain). Nat. Hazards Earth Syst. Sci. 2020, 20, 859-875. [CrossRef]

23. Aschonitis, V.G.; Papamichail, D.; Demertzi, K.; Colombani, N.; Mastrocicco, M.; Ghirardini, A.; Castaldelli, G.; Fano, E. Highresolution global grids of revised Priestley-Taylor and Hargreaves-Samani coefficients for assessing ASCE-standardized reference crop evapotranspiration and solar radiation. Earth Syst. Sci. Data 2017, 9, 615-638. [CrossRef]

24. Valle, L.C.G., Jr.; Ventura, T.M.; Gomes, R.S.R.; de S. Nogueira, J.; de A. Lobo, F.; Vourlitis, G.L.; Rodrigues, T.R. Comparative assessment of modelled and empirical reference evapotranspiration methods for a brazilian savanna. Agric. Water Manag. 2020, 232, 106040. [CrossRef]

25. Pandey, P.K.; Dabral, P.P.; Pandey, V. Evaluation of reference evapotranspiration methods for the northeastern region of India. Int. Soil Water Conserv. Res. 2016, 4, 52-63. [CrossRef]

26. Tabari, H.; Grismer, M.E.; Trajkovic, S. Comparative analysis of 31 reference evapotranspiration methods under humid conditions. Irrig. Sci. 2013, 31, 107-117. [CrossRef]

27. Samaras, D.A.; Reif, A.; Theodoropoulos, K. Evaluation of radiation-based reference evapotranspiration models under different mediterranean climates in central Greece. Water Resour. Manag. 2013, 28, 207-225. [CrossRef]

28. Quej, V.H.; Almorox, J.; Arnaldo, J.A.; Moratiel, R. Evaluation of temperature-based methods for the estimation of reference evapotranspiration in the Yucatán Peninsula, Mexico. J. Hydrol. Eng. 2019, 4, 5018029. [CrossRef]

29. Xystrakis, F.; Matzarakis, A. Evaluation of 13 empirical reference potential evapotranspiration equations on the island of Crete in Southern Greece. J. Irrig. Drain. Eng. 2011, 137, 211-222. [CrossRef]

30. Salam, R.; Islam, A.; Pham, Q.B.; Dehghani, M.; Al-Ansari, N.; Linh, N.T.T. The optimal alternative for quantifying reference evapotranspiration in climatic sub-regions of Bangladesh. Sci. Rep. 2020, 10, 20171. [CrossRef]

31. Jensen, M.E.; Allen, R.G. Evaporation, Evapotranspiration, and Irrigation Water Requirements. In ASCE Manuals and Reports on Engineering Practices No. 70; ASCE: New York, NY, USA, 2016.

32. Xu, J.; Peng, S.; Ding, J.; Wei, Q.; Yu, Y. Evaluation and calibration of simple methods for daily reference evapotranspiration estimation in humid East China. Arch. Agron. Soil Sci. 2013, 59, 845-858. [CrossRef]

33. Gao, F.; Feng, G.; Ouyang, Y.; Wang, H.; Fisher, D.; Adeli, A.; Jenkins, J. Evaluation of reference evapotranspiration methods in arid, semiarid, and humid regions. J. Am. Water Resour. Assoc. 2017, 53, 791-808. [CrossRef]

34. Gong, X.; Wang, S.; Xu, C.; Zhang, H.; Ge, J. Evaluation of Several reference evapotranspiration models and determination of crop water requirement for tomato in a solar greenhouse. HortScience 2020, 55, 244-250. [CrossRef]

35. Li, M.; Chu, R.; Islam, A.; Shen, S. Reference evapotranspiration variation analysis and its approaches evaluation of 13 empirical models in sub-humid and humid regions: A case study of the Huai River basin, Eastern China. Water 2018, 10, 493. [CrossRef]

36. Celestin, S.; Qi, F.; Li, R.; Yu, T.; Cheng, W. Evaluation of 32 simple equations against the Penman-Monteith method to estimate the reference evapotranspiration in the Hexi Corridor, Northwest China. Water 2020, 12, 2772. [CrossRef]

37. Zhao, S.; Yang, Y.; Zhang, F.; Sui, X.; Yao, Y.; Zhao, N.; Zhao, Q.; Li, C. Rapid evaluation of reference evapotranspiration in Northern China. Arab. J. Geosci. 2015, 8, 647-657. [CrossRef] 
38. Peng, L.; Li, Y.; Feng, H. The best alternative for estimating reference crop evapotranspiration in different sub-regions of mainland China. Sci. Rep. 2017, 7, 5458. [CrossRef]

39. Yang, Y.; Luo, Y.; Wu, C.; Zheng, H.; Zhang, L.; Cui, Y.; Sun, N.; Wang, L. Evaluation of six equations for daily reference evapotranspiration estimating using public weather forecast message for different climate regions across China. Agric. Water Manag. 2019, 222, 386-399. [CrossRef]

40. Fan, J.; Wu, L.; Zhang, F.; Xiang, Y.; Zheng, J. Climate change effects on reference crop evapotranspiration across different climatic zones of China during 1956-2015. J. Hydrol. 2016, 542, 923-937. [CrossRef]

41. Song, X.; Lu, F.; Xiao, W.; Zhu, K.; Zhou, Y.; Xie, Z. Performance of 12 reference evapotranspiration estimation methods compared with the Penman-Monteith method and the potential influences in northeast China. Meteorol. Appl. 2019, 26, 83-96. [CrossRef]

42. UNEP. World Atlas of Desertification. In World Atlas of Desertification; Middleton, N.J., Thomas, D.S.G., Eds.; Arnold: London, $\mathrm{UK}, 1997$.

43. Allen, R.G.; Pruitt, W.O. FAO-24 reference evapotranspiration factors. J. Irrig. Drain. Eng. 1991, 117, 758-773. [CrossRef]

44. Hargreaves, G.H.; Samani, Z.A. Reference crop evapotranspiration from temperature. Appl. Eng. Agric. 1985, 1, 96-99. [CrossRef]

45. Valiantzas, J.D. Simplified forms for the standardized FAO-56 Penman-Monteith reference evapotranspiration using limited weather data. J. Hydrol. 2013, 505, 13-23. [CrossRef]

46. Irmak, S.; Irmak, A.; Allen, R.G.; Jones, A.W. Solar and net radiation-based equations to estimate reference evapotranspiration in humid climates. J. Irrig. Drain. Eng. 2003, 129, 336-347. [CrossRef]

47. Valiantzas, J.D. Simple ET0 forms of Penman's equation without wind and/or humidity data. II: Comparisons with reduced set-FAO and other methodologies. J. Irrig. Drain. Eng. 2013, 139, 9-19. [CrossRef]

48. Rahimikhoob, A.; Behbahani, M.R.; Fakheri, J. An evaluation of four reference evapotranspiration models in a subtropical climate. Water Resour. Manag. 2012, 26, 2867-2881. [CrossRef]

49. Ngongondo, C.; Xu, C.-Y.; Tallaksen, L.M.; Alemaw, B. Evaluation of the FAO Penman-Montheith, Priestley-Taylor and Hargreaves models for estimating reference evapotranspiration in southern Malawi. Hydrol. Res. 2013, 44, 706-722. [CrossRef]

50. Islam, S.; Alam, A.R. Performance evaluation of FAO Penman-Monteith and best alternative models for estimating reference evapotranspiration in Bangladesh. Heliyon 2021, 7, e07487. [CrossRef]

51. Da Silva, R.D.; de Silva, M.A.; Canteri, M.G.; Rosisca, J.R.; Vieira Junior, N.A. Reference evapotranspiration for Londrina, Paraná, Brazil: Performance of different estimation methods. Semina Ciências Agrárias 2017, 38, 2363-2374. [CrossRef]

52. Mallikarjuna, P.; Jyothy, S.A.; Murthy, D.S.; Reddy, K.C. Performance of Recalibrated equations for the estimation of daily reference evapotranspiration. Water Resour. Manag. 2014, 28, 4513-4535. [CrossRef]

53. Issaka, A.I.; Paek, J.; Abdella, K.; Pollanen, M.; Huda, A.K.S.; Kaitibie, S.; Goktepe, I.; Haq, M.M.; Moustafa, A.T. Analysis and calibration of empirical relationships for estimating evapotranspiration in Qatar: Case study. J. Irrig. Drain. Eng. 2017, 143, 5016013. [CrossRef]

54. Nouri, M.; Homaee, M. On modeling reference crop evapotranspiration under lack of reliable data over Iran. J. Hydrol. 2018, 566, 705-718. [CrossRef]

55. Zhu, X.; Luo, T.; Luo, Y.; Yang, Y.; Guo, L.; Luo, H.; Fang, C.; Cui, Y. Calibration and validation of the Hargreaves-Samani model for reference evapotranspiration estimation in China. Irrig. Drain. 2019, 68, 822-836. [CrossRef]

56. Gentilucci, M.; Bufalini, M.; Materazzi, M.; Barbieri, M.; Aringoli, D.; Farabollini, P.; Pambianchi, G. Calculation of potential evapotranspiration and calibration of the hargreaves equation using geostatistical methods over the last 10 years in central Italy. Geosciences 2021, 11, 348. [CrossRef]

57. Kra, E. FAO-56 Penman-Monteith daily ET0 from linear regression calibrated Hargreaves equation with wind terms in tropics with limited data. Int. J. Agron. 2014, 2014, 402809. [CrossRef]

58. Morales-Salinas, L.; Ortega-Farías, S.; Riveros-Burgos, C.; Neira-Román, J.; Carrasco-Benavides, M.; López-Olivari, R. Monthly calibration of Hargreaves-Samani equation using remote sensing and topoclimatology in central-southern Chile. Int. J. Remote Sens. 2017, 38, 7497-7513. [CrossRef]

59. Sahoo, B.; Walling, I.; Deka, B.C.; Bhatt, B.P. Standardization of reference evapotranspiration models for a subhumid valley rangeland in the eastern Himalayas. J. Irrig. Drain. Eng. 2012, 138, 880-895. [CrossRef] 